Article

\title{
Hydrogen-An Alternative Fuel for Automotive Diesel Engines Used in Transportation
}

\author{
Alexandru Cernat ${ }^{1}$, Constantin Pana ${ }^{1}$, Niculae Negurescu ${ }^{1}$, Gheorghe Lazaroiu ${ }^{2, *}$, \\ Cristian Nutu ${ }^{1}$ and Dinu Fuiorescu ${ }^{1}$ \\ 1 Department of Thermotechnics, Engines, Thermal and Frigorific Equipment, University Politehnica of \\ Bucharest, 060042 Bucharest, Romania; cernatalex@yahoo.com (A.C.); constantinpana1@gmail.com (C.P.); \\ niculae_negurescu@yahoo.com (N.N.); nikolaoscristian87@gmail.com (C.N.); difuiore@yahoo.com (D.F.) \\ 2 Department of Energy Generation and Use, University Politehnica of Bucharest, 060042 Bucharest, Romania \\ * Correspondence: glazaroiu@yahoo.com; Tel.: +40-0722-808-709
}

Received: 13 October 2020; Accepted: 5 November 2020; Published: 10 November 2020

check for updates

\begin{abstract}
Considering the current environmental restrictions, particularly those imposed on fossil fuel exploitation, hydrogen stands out as a very promising alternative for the power and transportation sectors. This paper investigates the effects of the employment of hydrogen in a K9K automotive diesel engine. Experiments were conducted at a speed of $2000 \mathrm{~min}^{-1}$ with various engine load levels of $40 \%, 55 \%, 70 \%$, and $85 \%$; several quantities were monitored to evaluate the performance with hydrogen use in terms of brake-specific energetic consumption (BSEC), fuel economy, maximum pressure, and heat-release characteristics. It was found that at $55 \%$ engine load, the engine efficiency increased by $5.3 \%$ with hydrogen addition, achieving a diesel fuel economy of $1.32 \mathrm{~kg} / \mathrm{h}$. The rate of increase of the peak pressure and maximum pressure started to increase as a consequence of the higher fuel quantity that burned in the premixed combustion phase, while still remaining within reliable operational limits. The accelerated combustion and augmented heat release rate resulted in a combustion duration that was reduced by $3^{\circ} \mathrm{CA}$ (crank angle degree), achieving a mass fraction burned percentage of $10 \%$ to $90 \%$ earlier in the cycle, and the combustion variability was also influenced. Hydrogen use assured the decrease of $\mathrm{CO}_{2}, \mathrm{HC}, \mathrm{NO}_{\mathrm{x}}$, and smoke emission levels in comparison with classic fueling.
\end{abstract}

Keywords: combustion; diesel engine; hydrogen fuel; efficiency; heat-release rate; mass fraction burned; combustion variability

\section{Introduction}

\subsection{Pollutant Emissions in Automotive Engines}

The transportation sector causes a major part of the greenhouse gas emissions worldwide, but nowadays, sustainability and innovation in the automotive industry are based on new technologies [1], especially for internal combustion engines, which have an important place in the transportation field [2]. To mitigate the related environmental impact, restrictions are imposed to diminish these harmful emissions (which, in terms of greenhouse gas emissions, are estimated to add up to $20 \%$ for transportation) [3]. Specifically, severe limitations are set for unburned hydrocarbons (HC), carbon monoxide $(\mathrm{CO})$, carbon dioxide $\left(\mathrm{CO}_{2}\right)$, nitrogen oxides $\left(\mathrm{NO}_{\mathrm{x}}\right)$, particles, and smoke [1-6]. As the root of the generation of these pollutants is the automotive engine, it is remarked that $\mathrm{HC}$ and $\mathrm{CO}$ result as a consequence of incomplete combustion, while $\mathrm{NO}_{\mathrm{x}}$ (mainly nitrogen monoxide- $\mathrm{NO}$ and nitrogen dioxide $-\mathrm{NO}_{2}$, known as $\mathrm{NO}_{\mathrm{x}}$ emissions in the internal combustion engine (ICE) domain) is produced in the chemical reaction between nitrogen and oxygen unfolding in high-pressure conditions, such as 
the ones registered for in-cylinder combustion in engines [4]. Organic and inorganic components in the fuel supply (solid or liquid) are found in the exhaust gas as solid particles (PM). In more detail, they are formed based on a carbon-insoluble fraction (soot) and a soluble fraction that contains fuel and unburned oil. It is highlighted that the particles emitted by diesel engines have dimensions within the range from 0.01 to $1 \mu \mathrm{m}$, so they can easily enter the human lungs, therefore representing a major health threat. Smoke is composed of a suspension of liquid particles of unburned or partially burned fuel with diameters of up to $1 \mu \mathrm{m}$ (white or blue smoke), or of carbon particles with diameters greater than $1 \mu \mathrm{m}$ (black smoke) [4]. White and blue smoke appear under starting, idling, or low-load conditions when the engine thermal regime is reduced. Black smoke appears with increased loading operation, when the engine thermal regime is high.

For diesel engine operation, the largest share of the exhaust gases in terms of pollutant emissions belongs to nitrogen oxides, solid particles, and smoke [3-7]. As diesel engines are widespread in transportation, it is of crucial importance to significantly diminish the concentration of the pollutants and greenhouse gas emissions in the exhaust gas flows [8].

\subsection{Overview of Hydrogen Utilization in Automotives}

According to the Paris Agreement, signed by 200 countries at the United Nations Framework Convention on Climate Change in 2015, a series of proposals for the limitation of average global temperature increase and for pollutant emission concentration reduction have been introduced [7]. Furthermore, at the C40 Mayors Summit in Ciudad de Mexico held in 2016, a possible solution to the increased pollution in a few capitals (Paris, Athens, and Ciudad de Mexico) was considered to be the elimination of the automotive diesel engine by the year 2025 [8].

In this restrictive regulatory framework, the newest diesel engines must comply with the European Union standards regarding $\mathrm{NO}_{\mathrm{x}}$ and microparticle emissions. The European Commission aims to reduce $\mathrm{CO}_{2}$ emissions from transportation by $37.5 \%$ by 2030 . Thus, clean diesel engines, which have a $15 \%$ lower $\mathrm{CO}_{2}$ emission rate and a much lower specific fuel consumption compated to spark-ignition engines, represent a good solution. However, some innovative designs for improvement of the in-cylinder combustion process assume high costs and may be delayed in becoming profitable $[5,6]$. Moreover, the complexity of the engine increases. Therefore, employing alternative fuels emerges as a viable solution, enabling the replacement of fossil fuels and the reduction of pollutant emission concentrations $[5,6]$.

Several studies have demonstrated that employing alternative fuels reduces environmental pollution, as presented in [9-11]. Among these solutions, the use of hydrogen as fuel for ICEs (replacing oil products) has been proven to reduce the diesel engine pollutant emission level [12,13], while also improving the energetic performance reached in operation [14,15]. An important factor supporting hydrogen use for such purposes is that it is naturally widespread. Taking into account that $70 \%$ of the planet's surface is covered by water and that hydrogen is one of its constituents, this may represent an inexhaustible source, considering that one cubic kilometer contains almost 113,100 tones of hydrogen [16-18]. It is remarked that hydrogen has good combustion properties, qualifying it as the cleanest fuel for ICEs and enabling high combustion efficiencies compared to other alternative fuels $[19,20]$. Hydrogen is an easily flammable gas, is inodorous, insipid, and colorless, and is found in nature as a diatomic molecule, $\mathrm{H}_{2}$. Hydrogen is the lightest chemical element and is also the most prevalent element in the universe.

Regarding the storage of hydrogen, it can be in a liquid (in cryogenic reservoirs) or gaseous state (in pressurized reservoirs) on-board an automotive. Liquid-state storage is difficult because hydrogen has a very low boiling point $\left(-253^{\circ} \mathrm{C}\right)$, resulting in multiple technical and safety requirements and constraints. Gas-state storage presents the disadvantage of needing a relatively large volume of reservoirs because of hydrogen's low density (for instance, to substitute the quantity of diesel fuel that is stored in a $70 \mathrm{~L}$ reservoir, 11,720 L of compressed hydrogen is necessary) [21]. 
Hydrogen requires a much lower quantity of vaporization heat, implying a lower heat self-consumption if the fuel is directly injected in liquid state. The solubility of hydrogen in liquids is very low, and some metals dissolve hydrogen at high temperatures, forming interstitial hydrides. Due to its molecular mass, hydrogen has higher specific mass heat and heat conductivity compared to other gases [22]. Instead, the dynamic viscosity of hydrogen is two times lower compared to that of air. The very high diffusion velocity showed by hydrogen ensures good homogeneity mixtures in blends with other gases $[23,24]$. However, increased diffusion of hydrogen in thin holes or porous walls leads to negative effects on metal structures (according to some researches, the hydrogen diffusion velocity is 7.8 times higher comparative to gasoline [21]), and special storing conditions are required. High octane number makes hydrogen an ideal fuel for spark ignition engines with high compression ratios, but the raised autoignition temperature and lower cetane number define hydrogen as a fuel with inferior autoignition properties, and specific methods for hydrogen fueling must be applied for diesel engines. Hydrogen has wide flammability limits in air $\left(4.1 \%_{\mathrm{v}}\right.$ inferior limit $-75.6 \%_{\mathrm{v}}$ superior limit) [15]. An important advantage of hydrogen use is the possibility of ultralean engine operation; in other words, the air-fuel ratio can be very high (over $\lambda=10.8$ ), enabling an appreciable engine cycle efficiency improvement, i.e., around 38\% [18]. Because the flame temperature in hydrogen combustion is much higher and ultralean mixtures are fed to the engine, nitrogen oxides levels augment, requiring treatment of the exhaust gases.

Experimental investigations carried out on hydrogen fueled ICEs have highlighted certain specific effects of its combustion versus diesel fuel $[14,25]$. Specifically, by increasing the hydrogen quantity, the peak pressure slightly increases in reduced loading conditions, while it rapidly increases at higher loads. This is a consequence of a smaller delay in diesel fuel autoignition, correlating with the higher combustion rate of hydrogen compared to that of diesel fuel $[26,27]$. The same trend applies to the maximum pressure rise rate $[27,28]$. Both parameters can be used for hydrogen addition optimization in order to limit mechanical stress on the engine $[18,29]$.

Regarding the engine thermal efficiency, it has been observed that it increases with an increase in the hydrogen quantity in the diesel fuel blend, due to the improvement of the combustion process [30,31]. For greater engine loads (60-80\%), the thermal efficiency sharply decreases because of the incomplete combustion of a rich mixture [32-34]. Furthermore, the maximum heat release rate increases by incrementing the hydrogen share in diesel fuel blends due to the higher combustion velocity of such mixtures (hydrogen has a nine times larger combustion velocity compared to diesel) [35-37]. For small hydrogen quantities, improved combustion ensures a decrease of $\mathrm{CO}$ and $\mathrm{HC}$ emissions levels, but further hydrogen addition leads to incomplete combustion, producing an increase in such emissions $[35,36]$. Some researchers have even demonstrated that the HC emissions increase regardless of the hydrogen amount, with a proportional $\mathrm{O}_{2}$ intake reduction [31].

In reference to smoke emissions, it is noteworthy that the use of hydrogen in diesel engines achieves marked reductions due to improvements in the combustion process and a decrease in the grade of carbon concentrations from the cyclic fuel dose [38].

Compared to exclusive diesel fueling, by using a hydrogen-diesel blend with small to medium engine loads, the $\mathrm{NO}_{\mathrm{x}}$ emissions depend on the hydrogen share, decreasing with small amounts of hydrogen and increasing with higher ratios (because of higher temperatures during combustion) [39].

According to the aforementioned observations, it has been demonstrated in the literature that hydrogen may be suitable as partial substitute of diesel fuel in CIEs, enabling also a reduction in exhaust gas emissions [40,41].

Different researchers have used hydrogen as fuel for different internal combustion engines in order to improve engine performance and reduce pollution. For example, Shin [42] used hydrogen to fuel a two-liter diesel engine with an operating regime of $1500 \mathrm{rev} / \mathrm{min}$ speed and a $2.5 \mathrm{~kg} / \mathrm{h}$ diesel fuel rate. Through the addition of hydrogen, $\mathrm{NO}_{\mathrm{x}}$ emission levels decreased, and combustion duration and the maximum pressure increased. 
Das [43] defines hydrogen as a clean alternative fuel whose use leads to improved thermal efficiency and reductions in $\mathrm{NO}_{\mathrm{x}}$ emissions without abnormal combustion phenomena in lean mixture operation.

Dell [44] promotes the use of hydrogen as an alternative fuel which is economically and environmentally feasible in automotive and truck engines. Moreover, affirms that the hydrogen combustion in internal-combustion engines is totally different to that of classic fuels, and requires special design modifications, because hydrogen's low ignition energy and rapid flame speed lead to phenomena like preignition, backfire and knock.

Sorensen [45] confirmed that the thermal engine efficiency increase with the use of hydrogen in diesel and spark ignition engines is due to hydrogen's higher combustion speed. Sorensen [26] observed the rate of consumption of injected hydrogen. If hydrogen is fed into the cylinder from a specific side, a zone of "unused" oxygen appears in the combustion chamber, i.e., the oxygen distribution inside the combustion chamber is affected. The author proposes the use of catalytic converters to reduce $\mathrm{NO}_{\mathrm{x}}$ emission levels [45].

Verhelst [46] presented an overview of hydrogen internal combustion engines and highlighted the increase of engine efficiency and the reduction of pollutant emissions.

Mansor [47] used hydrogen and methane to fuel a diesel engine and observed that if the diesel fuel cyclic quantity is raised, then the in-cylinder maximum pressure decreases and the ignition delay is reduced. With an increase of hydrogen quantity, the maximum pressure increases significantly and the autoignition delay starts to decrease. This higher maximum pressure corresponds to higher hydrogen contents [47]. Also, for higher hydrogen ratios, the combustion temperature and the NO emission levels are higher. Finally, Mansor proposes the use of small hydrogen quantities in order to achieve lower combustion temperatures, thereby improving the thermal efficiency, i.e., with reduced thermal losses [47].

Sandalci [48] used hydrogen addition to fuel a diesel engine with an operating regime of $5.1 \mathrm{~kW}$ and $1300 \mathrm{rev} / \mathrm{min}$. The hydrogen is injected into the intake manifold, and the air-hydrogen mixture is ignited by a diesel fuel pilot. Regarding the use of hydrogen, Sandalci observed a reduction in smoke emissions, an acceleration of premixed combustion and an increase in maximum pressure proportional to the ratio of hydrogen in the fuel [48]. However, for large hydrogen contents, the $\mathrm{NO}_{\mathrm{x}}$ emission levels increased, the thermal efficiency decreased and fuel consumption increased [48].

Dhole [49] used hydrogen as a secondary fuel for a diesel engine, with good results in terms of thermal efficiency (i.e., a 6 to $10 \%$ increase, depending engine load and hydrogen content) and $\mathrm{NO}_{\mathrm{x}}$ emission level reductions (i.e., a $63 \%$ decrease with small engine loads and $32 \%$ decrease with large loads) [49].

Karagöz [50] used hydrogen as an additive fuel in a CFR diesel engine with a full load regime and different speeds; a decrease of smoke and $\mathrm{CO}_{2}$ emissions levels, a significant increase in $\mathrm{NO}_{\mathrm{x}}$ emission level and a slight increase in $\mathrm{HC}$ were observed. The maximum vales of in-cylinder pressure and heat release increased with the addition of hydrogen [50]. Kavtaradze [51] noted that in-cylinder processes are fundamentally different with hydrogen diesel compared to classic diesel fuel, with influences on combustion parameters and pollution performance. In this regard, Kavtaradze [51] conceded that hydrogen diesel engines are a new field of investigation, and that this topic has not yet being sufficiently investigated. Therefore, Kavtaradze [51] used hydrogen to fuel a single cylinder MAN diesel engine; a 920 ppm of NO, an nine-bar mean effective pressure and a 0.48 efficiency indicator were achieved. Based on these experiments, Kavtaradze [51] confirmed that hydrogen is a suitable fuel for diesel engines and could be successfully used to reduce pollution emissions.

Ghazal [52] investigated the effect of the use of a hydrogen/diesel fuel and water injection in engine ports on the operation of a diesel engine. Ghazal's simulation showed that an increase of hydrogen flow, in correlation with water flow, led to increased combustion temperature, NO emission levels, engine power and brake specific fuel consumption, as well as of thermal efficiency, at high engine speeds [52]. With a decrease of injection timing, engine efficiency was affected and the emission of NO also increased, while CO emission levels decreased [52]. At a specific engine speed, i.e., $3000 \mathrm{rev} / \mathrm{min}$, and at 
higher injection timing, the $\mathrm{CO}$ emissions decreased, but higher in-cylinder pressure, pressure rates and temperatures led increased fuel consumption, NO emission levels and operating vibrations [52]. Even with a constant flowrate of hydrogen, in-cylinder pressure, temperatures and emissions level started to increase [52]. Ghazal [52] decreased the injection timing in order to reduce NO and CO emissions levels to an acceptable level.

Monemian [53] defines hydrogen as a "long-term fuel solution" for diesel engines, and used it to partially substitute traditional fuel in a single cylinder HD diesel engine. At higher hydrogen doses, Monemian [53] observed increased engine efficiency, with a corresponding decrease in $\mathrm{CO}_{2}$ emission levels of $32 \%$ up to $58 \%$, depending on engine load [53]. At small loads, $\mathrm{CO}$ and soot emissions were shown to decrease with hydrogen use [53]. With a constant injection moment, the $\mathrm{NO}_{\mathrm{x}}$ emission levels increased by $26 \%$ under an average engine load, and by $56 \%$ under a higher load because of the increased combustion temperature [53]. Lešnik [54] identified hydrogen as a viable solution to improve the technology level of modern internal combustion engines. In his study, he espouses the benefits of hydrogen use, especially in heavy-duty, commercial automotive, or passenger car diesel engines, in terms of reductions of pollutant emissions [54]. Lešnik further affirms that, in the future, internal combustion engines will continue to play an important role in road transportation [54]. Yip [55] studied the use of hydrogen in internal combustion engines, focusing in part on diesel engines and analyzing different types of fueling solutions. It was observed that the use of a diesel fuel pilot in order to ignite the air-hydrogen mixture as an operating mode of dual fueled diesel engines (hydrogen and diesel fuel) eliminated issues of hydrogen use in spark ignition engines and yielded reduced pollutant emissions compared to traditional diesel engines [55]. Yip [55] states that a fueling system that ignites a hydrogen-air mixture using a diesel fuel pilot may be viable in the future. Regarding hydrogen use, Yip [55] observed the possibility of decreasing CO and smoke emissions by up to $50 \%$, depending on the hydrogen dose. The $\mathrm{NO}_{x}$ emission levels may increase, but this is dependent on the hydrogen fueling method, and further reductions can be achieved [55]. Saroj [56] noted that hydrogen is a nonpolluting energy source which may be used to fuel diesel engines in a dual fuel formula with biogas. Saroj [56] observed that dual fueling led to an increase of brake specific fuel consumption by $36 \%$, compared to traditional engines. For dual fuel mode operation, the maximum pressure increase was $23 \%$ and the heat release rate increased by $30 \%$ [56]. Compared to the use of traditional fuels, the $\mathrm{NO}_{\mathrm{x}}$ emission and smoke emission levels were reduced by $20 \%$ and $60 \%$, respectively, but CO emission levels increased by 30\%, according to Saroj [56]. Finally, Saroj concluded that hydrogen supply can improve the performance of diesel engines fueled by biogas [56].

\subsection{Aim of Research}

The accelerated depletion of oil reserves highlights the necessity of alternative fuels, especially from durable and renewable resources, such as hydrogen, which may be produced from plants $[1,2,5,6,9]$. While this paper presents some challenges, its main objective is to study the increase in the energetic performance of automotive diesel engines through the addition of hydrogen to diesel fuel. On one hand, hydrogen has a lower energy density compared to diesel, so an adequate design of fueling systems must be developed, in order to keep the engine power constant. On the other hand, the inferior autoignition properties of hydrogen necessitate the application of methods which are specific to hydrogen fueling. So our main objective, i.e., measuring the increase in the energetic performance of automotive diesel engines by the addition of hydrogen to the fuel, requires the use of a fueling method which is easy to apply and suitable for all diesel engines. The diesel-gas method, which is considered easy to apply to old or new diesel engine designs, was used as the fueling method. This paper presents some experimental results of hydrogen use in a diesel engine. The authors studied the influence of the hydrogen cyclic dose on the energetic and combustion performance of the engine.

The novelty aspect of this research is its determination of the optimal correlation among engine operating regime, fuel cyclic dose, combustion parameters and pollutant emissions, in order to apply these data to a modern diesel engine. The hydrogen-diesel fueling system designed by authors 
is electronic controlled and actuated by a Dastek Unichip Program via on open ECU Unichip unit, which adjusts the cyclic doses of the fuels (hydrogen and diesel fuel) in order to maintain the engine power according to a reference engine. Thus, the fueling system developed by the authors can be used with modern automotive diesel engines equipped with electronic control, for operation under variable load and speed regimes. In terms of the added hydrogen, if the quantities are small, the novelty is reflected in the possibility of the use of an on-board hydrogen generator. The fueling system is designed to be versatile, i.e., switching to classic fueling is possible anytime. Additionally, it does not require modifications to be made to the engine. The optimal correlation of the aforementioned variables makes it possible to control the $\mathrm{NO}_{x}$ emission levels without exceeding the levels resulting from the use of traditional fuels, as well as to continuously decrease HC.

To accomplish this objective, experimental investigations were carried out at $40 \%, 55 \%, 70 \%$ and $85 \%$ engine loads, and at $5 \%, 10 \%, 15 \%$ and $20 \%$ ratios of diesel fuel to hydrogen. Beside the advantage of reduced dependence on traditional fuels, hydrogen offers the advantages of reduced diesel fuel consumption and improved combustion. The reduction in diesel fuel consumption, with $1.32 \mathrm{~kg} / \mathrm{h}$ less diesel fuel consumed at $55 \%$ engine load, appears to be due to improved engine efficiency and to the combustion process, in terms of an accelerated heat release rate, more rapid mass fraction burned per cycle, and higher values of maximum pressure and rate of maximum pressure increase under normal engine operation conditions. This last aspect was evaluated by an analysis of engine response to combustion variability with hydrogen use-with the coefficients of variability for IMEP and maximum pressure in the normal range-using a normal engine running on dual fueling.

\section{Experimental Investigations Design}

This paper investigates the effects of a hydrogen mixture with diesel in a supercharged $\mathrm{K} 9 \mathrm{~K}$ diesel engine. To this end, the engine was fueled with diesel fuel and hydrogen at different proportions. Additionally, the engine loading was varied from $40 \%, 55 \%, 70 \%$ and $85 \%$ for a constant operational speed of $2000 \mathrm{~min}^{-1}$. The combustion characteristics and engine performance were assessed, as described below.

The test bench designed to evaluate the performance of the hydrogen diesel engine is shown in Figure 1. The fueling system was equipped with an open-type ECU which was connected to a fueling system and controlled by a computer running the Dastek Unichip software. To maintain the engine power with an increase of hydrogen cyclic quantity, the diesel fuel was reduced. The fuel quantities were electronic managed by controlling the duration of open injectors. The durations of the injections were established in concordance with engine regime/combustion parameters and pollutant emissions.

Table 1 presents the main characteristics of the equipment.

Table 1. Main characteristics of test bed equipment.

\begin{tabular}{cccc}
\hline Measured Parameter & Measurement Device & Unit & Uncertainties \\
\hline Engine speed & Horiba Schenck E90 & $\mathrm{rev} / \mathrm{min}$ & $\pm 1 \mathrm{rev} / \mathrm{min}$ \\
Engine torque & Horiba Schenck E90 & $\mathrm{Nm}$ & $\pm 0.2 \%$ \\
Diesel flow rate & Optimass 3050 C & $\mathrm{kg} / \mathrm{h}$ & $\pm 0.1 \%$ \\
Hydrogen flow rate & Alicat Scientific MCR & $\mathrm{kg} / \mathrm{h}$ & $\pm 0.4 \%$ \\
Inlet air flow rate & Krohne H 250 & $\mathrm{m} 3 / \mathrm{h}$ & $\pm 0.35 \%$ \\
In-cylinder pressure & AVL GU 12 P & $\mathrm{bar}$ & $\pm 0.05 \%$ \\
Crank angle degree & AVL 365 CC & ${ }^{\circ} \mathrm{CA}$ & $\pm 0.1 \%$ \\
& Thermocouple Cromel-Alumel TTC & ${ }^{\circ} \mathrm{C}$ & $\pm 1{ }^{\circ} \mathrm{C}$ \\
Temperatures & Thermoresistence Pt100 TTR & ${ }^{\circ} \mathrm{C}$ & $\pm 2{ }^{\circ} \mathrm{C}$ \\
& Shimaden SR93 indicators & ${ }^{\circ} \mathrm{C}$ & $\pm 0.3 \%$ \\
\hline
\end{tabular}




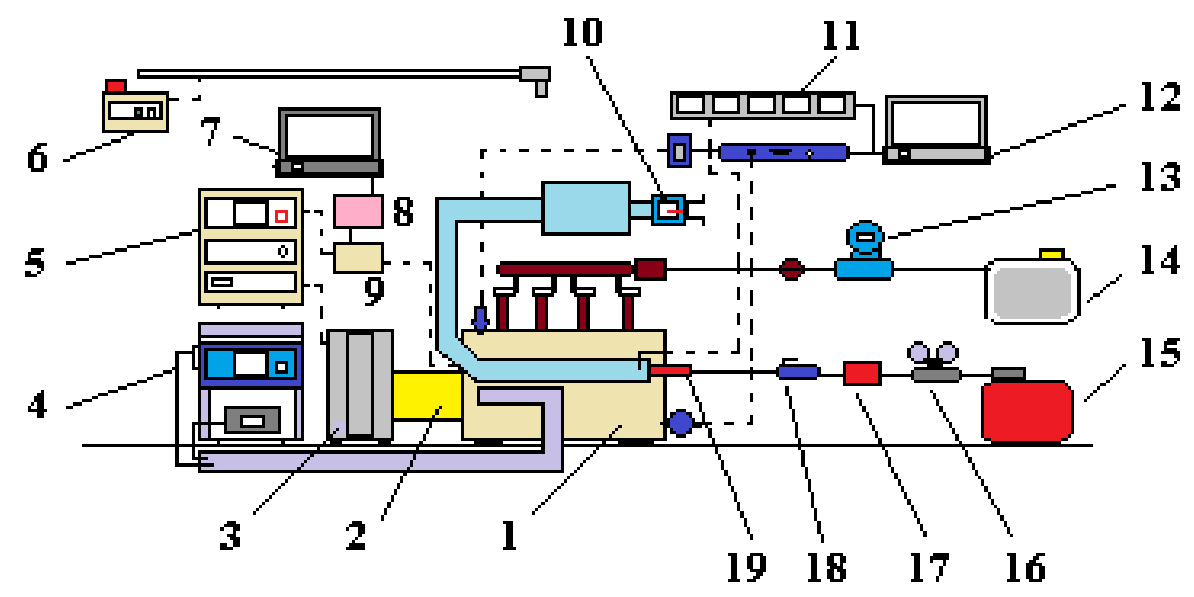

Figure 1. The hydrogen-diesel engine test bench, comprising the following parts: 1—supercharged four cylinder K9K diesel engine; 2-Voith coupling shaft; 3-Horiba Schench eddy current dyno; 4-AVL DiCom 4000 gas analyzer and opacimeter; 5-dyno control cabinet; 6-test cell safety sensor for hydrogen detection; 7-Dastek Unichip computer; 8-Unichip Q; 9-ECU of K9K engine; 10—Krohne air flowmeter; 11-Shimaden supercharging pressure and temperature indicators; 12-AVL data acquisition system (AVL Indimodul Card C1 acquisition board, AVL Indimodul 621, AVL-3067A01 charge amplifier, AVL-GU12P pressure transducer and AVL-365CC angle encoder); 13-Optimass diesel fuel flowmeter; 14-diesel fuel reservoir; 15-hydrogen reservoir; 16-hydrogen pressure regulator; 17-Alicat Scientific MCR hydrogen flowmeter; 18-flame arrestors; 19-hydrogen injector.

At the beginning of the experimental procedure, all the experimental instruments and the equipment were calibrated. The diesel engine was designed by the authors $[26,28]$ and included a hydrogen fueling system with an embedded hydrogen injector connected to the inlet manifold, a flame arrestor, a pressure regulator and a hydrogen reservoir. In order to monitor the hydrogen flow, a dedicated flowmeter was installed on the fuel line. The hydrogen injector was set in motion from a computer running the Dastek Unichip software (an Unichip electronic unit connected with the ECU of the K9K engine). The Unichip unit controlled the opening durations of the diesel fuel inlet and hydrogen injectors, thereby reducing the diesel fuel cyclic amount with an increase of hydrogen flow in order to keep the output brake power constant at the level of standard fueling. In this way, different hydrogen flows were set, so the energetic substitute ratio was modified. Thus, it was possible to ensure the best correlation between engine running regime, fuel cyclic quantities, in-cylinder peak pressure, pollutant emissions levels and exhaust gas temperature for high engine efficiency when using hydrogen. This represents a novel aspect introduced by this research. For each engine operating regime, the diesel fuel and hydrogen flows, emissions levels, supercharging pressure, temperatures of the exhaust gases, inlet air, oil and cooling liquid and number of 250 pressure diagrams were monitored.

\section{Results and Discussions}

The variation ratio (VC) is defined according to Equation (1) [41]:

$$
\mathrm{VC}=\frac{\sqrt{\frac{1}{n} \cdot \sum_{i=1}^{n}\left(x_{i}-\frac{\sum_{i=1}^{n} x_{i}{ }^{2}}{n}\right)}}{\frac{\sum_{i=1}^{n} x_{i}}{n}}
$$

A set of three measurements were recorded for each engine load regime. The VC was used to evaluate the measurement error for the results. Due to the stability of the operating regimes, the VC values calculated for all measures (engine brake torque, engine speed, brake fuels consumptions, 
gas temperature) did not exceed $1 \%$. Thus, the data spread was narrow, the measurement sample was uniform and the $\mathrm{VC}$ value was below the limit of convergence for each measured dataset.

Figure 2 presents the Brake Specific Energetic Consumption (BSEC) variation versus xc substitute ratios at different engine loads. For each engine load, the specific energy consumption decreased with an increase of xc due to an improved mixing process of hydrogen and air, and to improved combustion. At partial loads of $40 \%$ and $55 \%$, for maximum xc, the BSEC decreased by $8.16 \%$ and $4.16 \%$, respectively. For high loads (85\%) the BSEC slowly increased because the inlet air quantity decreased.

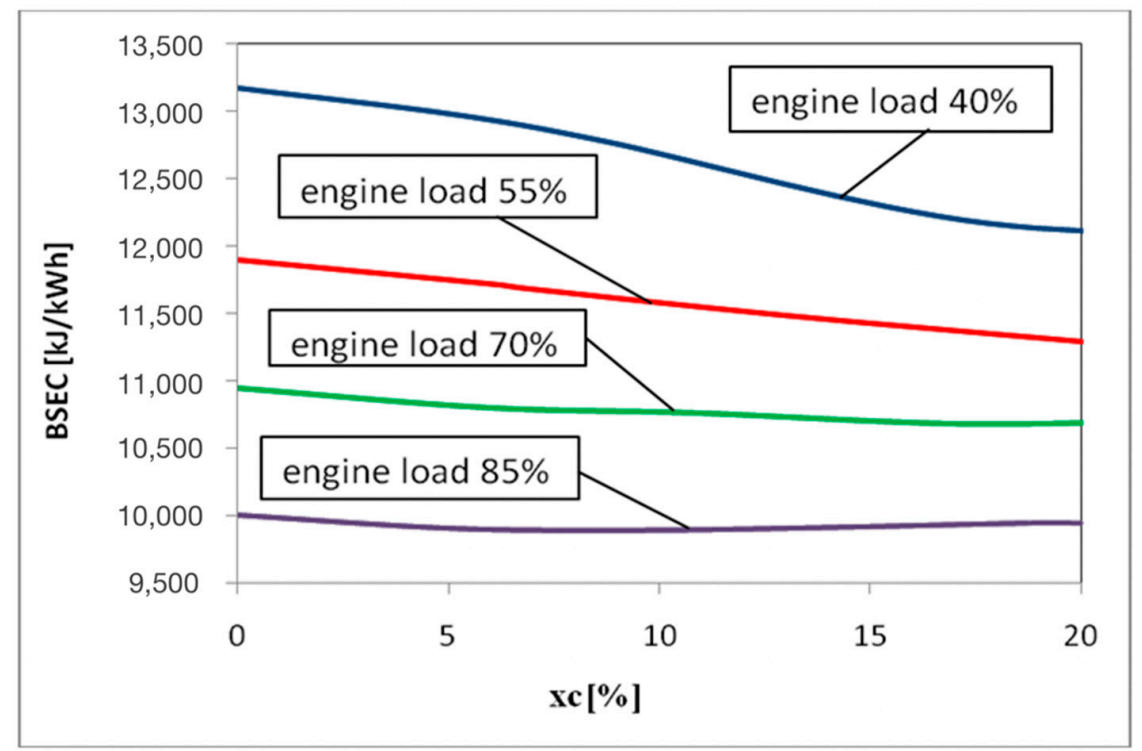

Figure 2. Break Specific Energetic Consumption versus substitute ratio at different engine loads and $2000 \mathrm{~min}^{-1}$ speed.

Figure 3 presents the variation of the BSEC versus engine load for $2000 \mathrm{~min}^{-1}$ speed and different xc substitute ratios. As shown in Figures 3-5, hydrogen fueling with flows ensuring maintained engine power at the same load and speed, in terms of diesel fuel consumption, yielded a significant economy of diesel fuel and a lower energetic specific consumption.

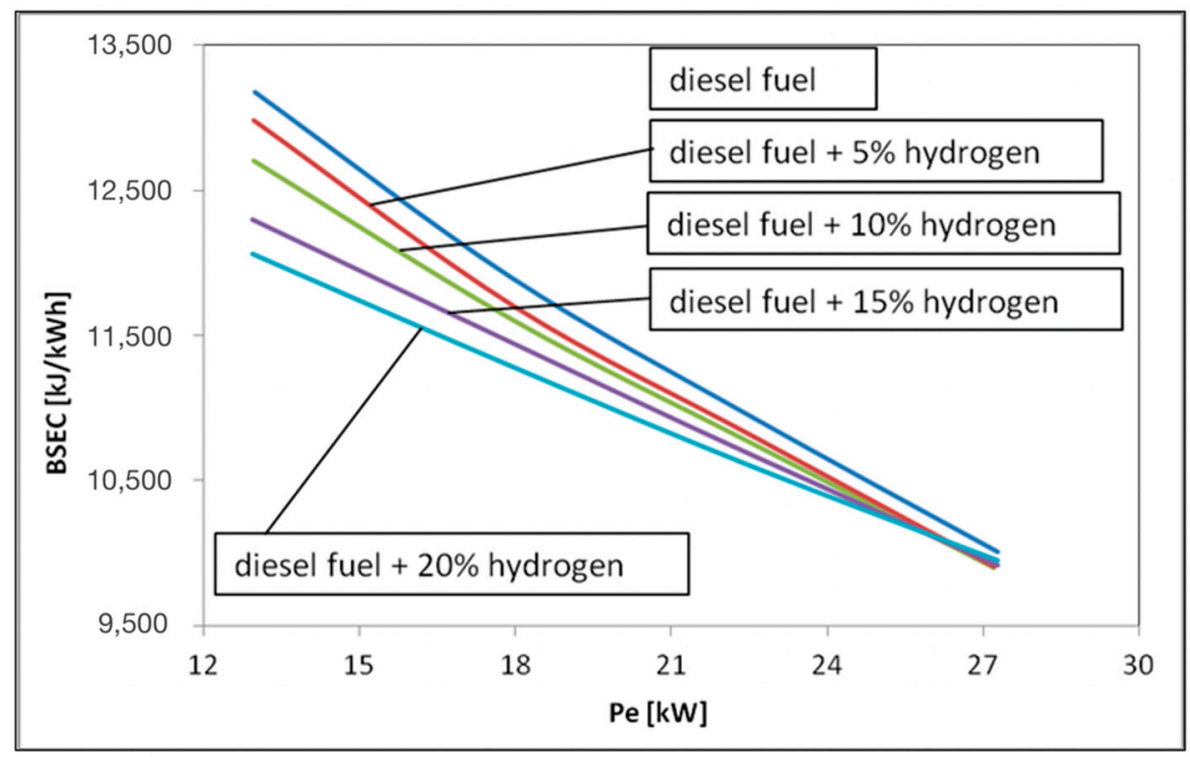

Figure 3. Brake Specific Energetic Consumption versus engine load at $2000 \mathrm{~min}^{-1}$ speed and different substitute ratios. 


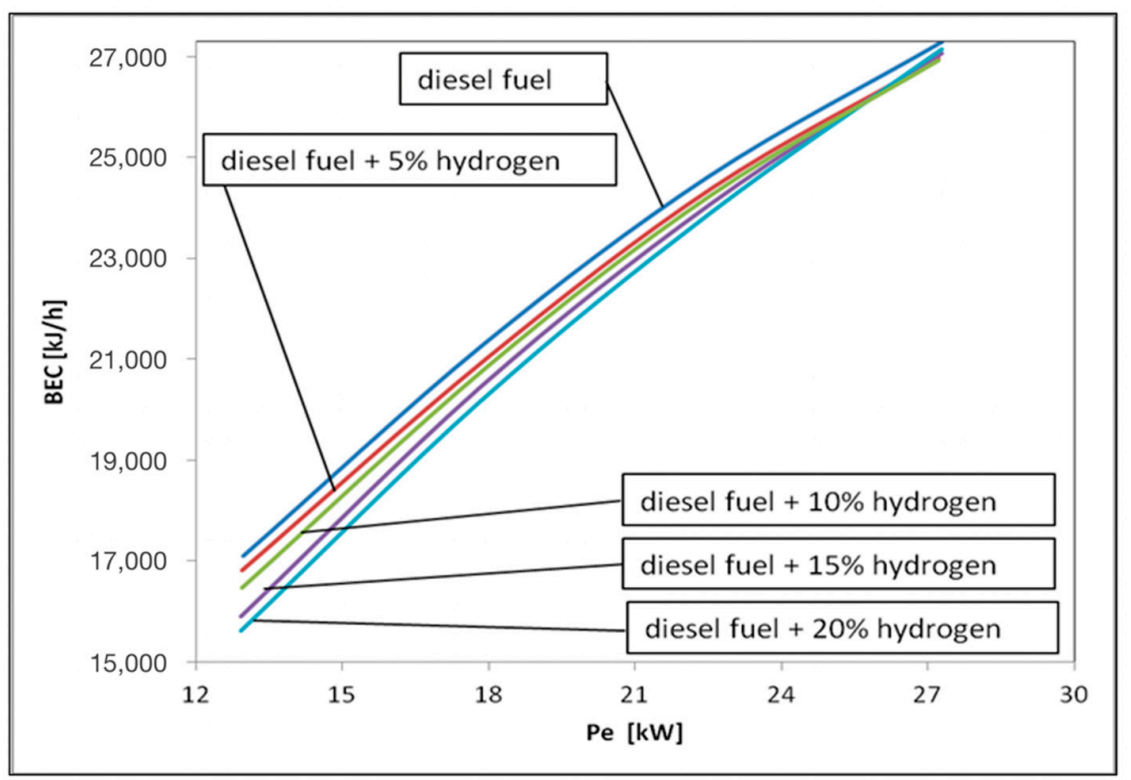

Figure 4. Brake Energy Consumption versus engine load at a speed of $2000 \mathrm{~min}^{-1}$ and different substitute ratios.

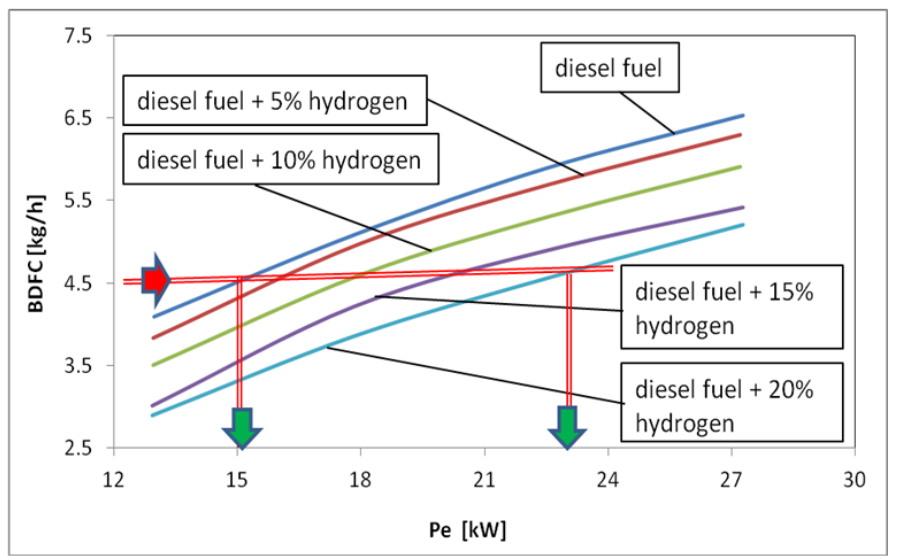

Figure 5. Brake Diesel Fuel Consumption versus engine load at a speed of speed $2000 \mathrm{~min}^{-1}$ and different substitute ratios.

Figures 4 and 5 present the variation of the Break Energy Consumption (BEC) and the Brake Diesel Fuel Consumption (BDFC), respectively, versus engine load at $2000 \mathrm{~min}^{-1}$ and using different substitute ratios.

For example, at $55 \%$ engine load $\left(\mathrm{P}_{\mathrm{e}}=18 \mathrm{~kW}\right)$, the economy of diesel fuel was $1.32 \mathrm{~kg} / \mathrm{h}$ and the diesel engine efficiency $\eta$ was increased by $5.3 \%$; see Figure 6 . For hydrogen and diesel fueling, with the same diesel fuel consumption, the engine operating load range increased and the engine power increased from $15 \mathrm{~kW}$ to $22.5 \mathrm{~kW}$; see Figure 5 .

Figure 7 presents averaged pressure diagrams $\mathrm{p}-\alpha$ for classic fueling $(\mathrm{xc}=0)$ and for hydrogen addition $(\mathrm{xc}=6.76 \%, \mathrm{xc}=13.39 \%$ and $\mathrm{xc}=20.97 \%)$, at $55 \%$ engine load and a speed of $2000 \mathrm{~min}^{-1}$. The combustion intensification and the reduction of droplet combustion duration in the presence of an air-hydrogen mixture are in correlation with the increasing tendency observed during our experiments regarding the peak pressure and maximum pressure rise rate; see Figures 7-9. 


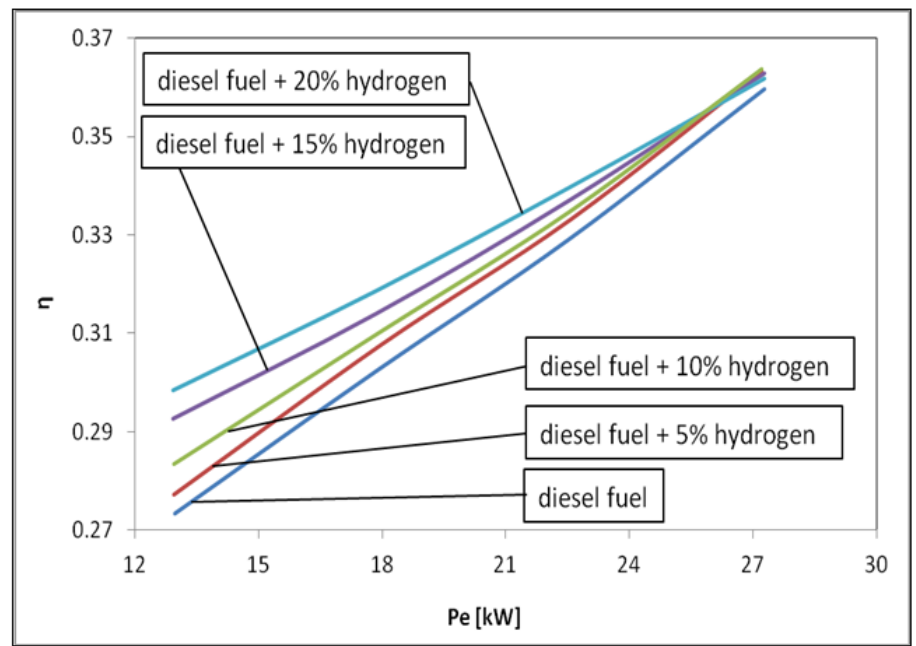

Figure 6. Brake Efficiency versus engine load at a speed of $2000 \mathrm{~min}^{-1}$ and different substitute ratios.

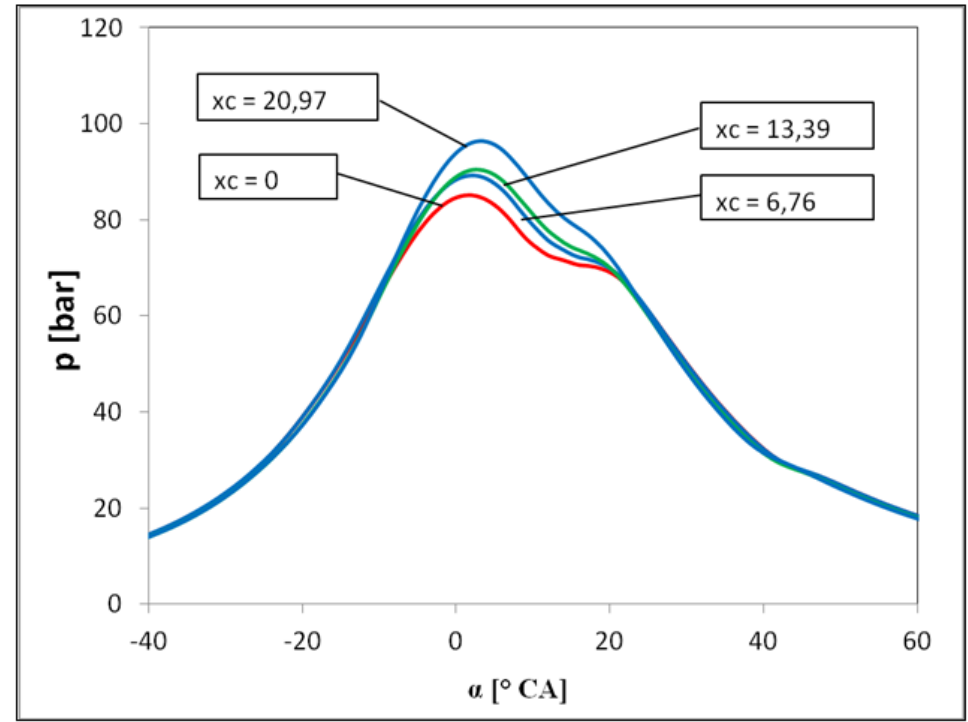

Figure 7. Pressure diagrams at 55\% engine load and a speed of $2000 \mathrm{~min}^{-1}$ for different substitute ratios.

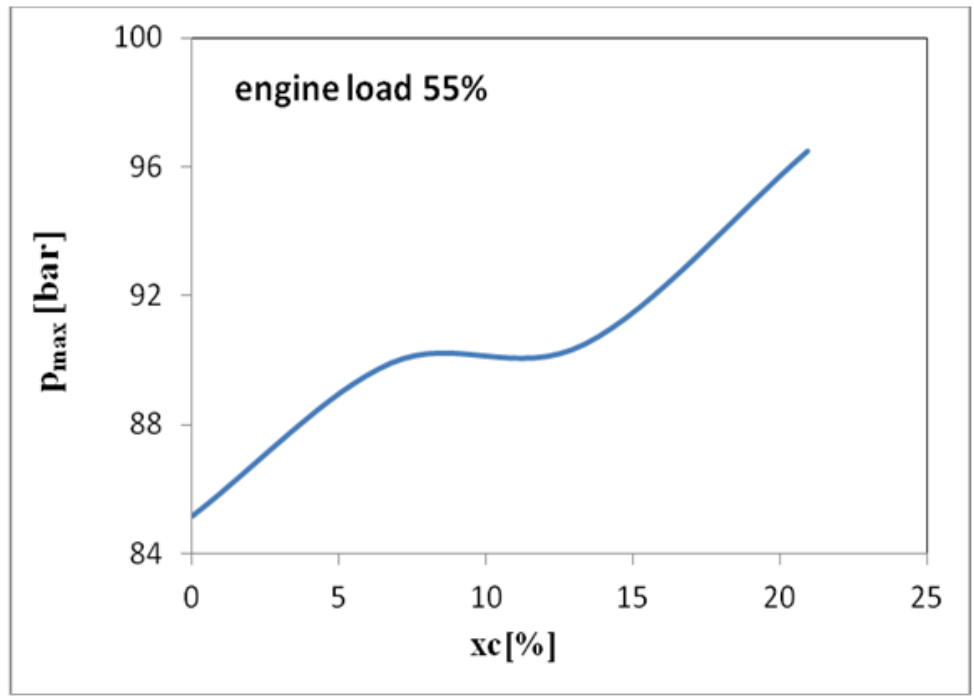

Figure 8. Peak pressure versus substitute ratio at $55 \%$ engine load and a speed of $2000 \mathrm{~min}^{-1}$. 


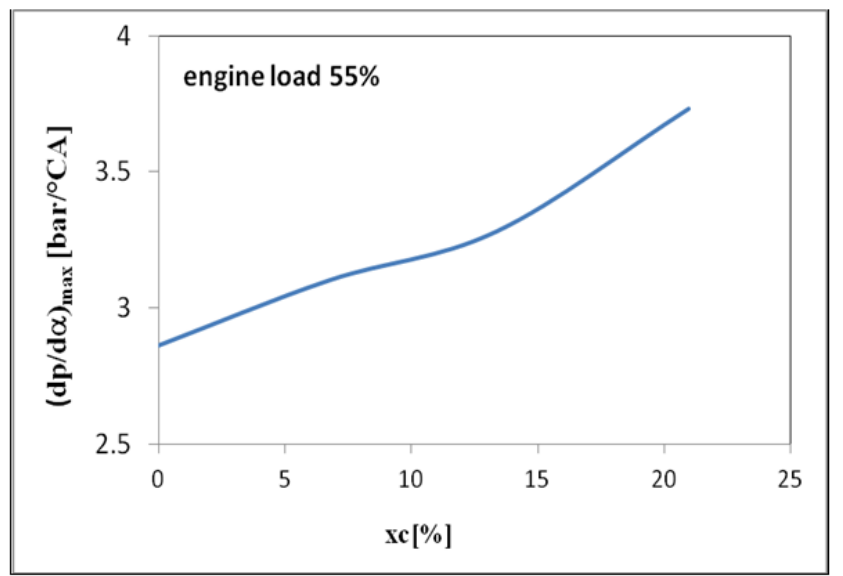

Figure 9. Maximum pressure rise rate versus substitute ratio at 55\% engine load and a speed of $2000 \mathrm{~min}^{-1}$.

The peak pressure $p_{\max }$ and the maximum pressure rise rate $(\mathrm{dp} / \mathrm{d} \alpha)_{\max }$ began to rise with the addition of hydrogen (see Figures 8 and 9) due to the increase in the fuel being burned in the premixed stage. The higher combustion speed and calorific value of hydrogen ensured the increase of heat release during the early stages of combustion (see Figure 10) in correlation with the increase in the values of in-cylinder peak pressure and maximum rate of pressure rise (see Figures 7-9). Thus, compared to diesel, the addition of hydrogen led to an increase of peak pressure by $6 \%$ for $\mathrm{xc}=6.76$ and 13.39 , and by $13 \%$ at $x c=20.97$.

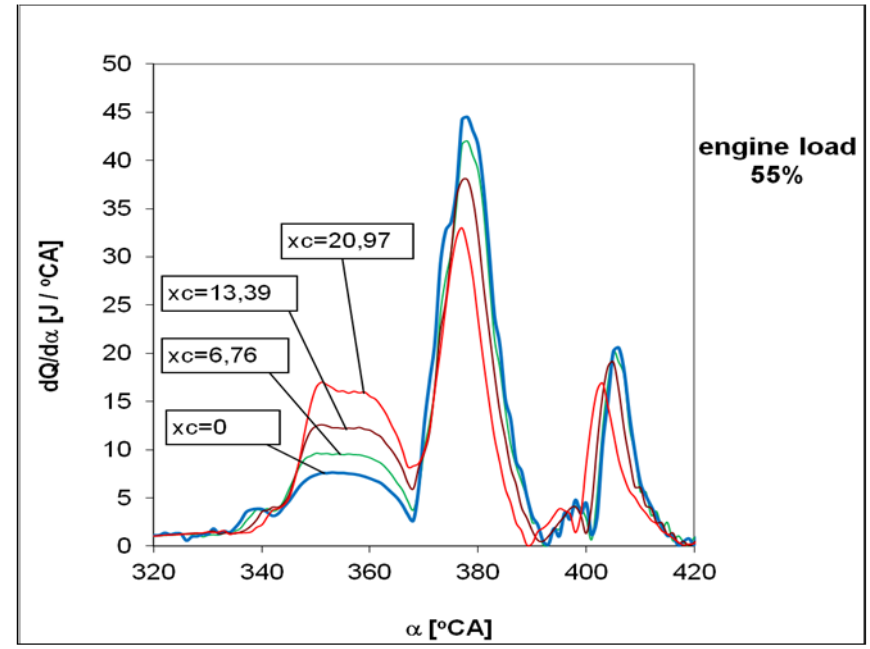

Figure 10. Heat release rate for different substitute ratios at $55 \%$ engine load and a speed of $2000 \mathrm{~min}^{-1}$.

The maximum value of pressure rise rate started to increase from $7.6 \%$ to $14 \%$ for $\mathrm{xc}=6.76$ to 13.39 , and by $29 \%$ at $x c=20.97$. The reached values did not affect engine reliability, as the usual range of values was not exceeded; however, the tendency of these values to increase may be considered as a limitation regarding the portion of hydrogen to be used. Similar results of maximum pressure increase with the use of hydrogen were also recorded in experiments presented elsewhere [42,47,48,50,52].

With diesel-hydrogen fueling, due to the increase of fuel quantity which combusted in the rapid stage, in correlation with the higher heating value and combustion rate of hydrogen, the rate of heat released $(\mathrm{dQ} / \mathrm{d} \alpha)$ into the combustion premixed stage increased; see Figure 10. The higher combustion speed of hydrogen accelerated the release of heat, appearing sooner per cycle, with 3 crank angle degrees for $\mathrm{xc}=20.97$. Due to the increased calorific value of the hydrogen fuel, the peak of heat release rate during the first stage of combustion started to rise, reaching $28.6 \%$ at $\mathrm{xc}=6.76,68 \%$ at $\mathrm{xc}=6.76$, and $126 \%$ at $\mathrm{xc}=20.97$; this tendency correlated with the increased variation of maximum 
pressure and rate of pressure rise. The acceleration of the premixed mixture combustion was consistent results reported elsewhere $[42,47,48,52,56]$.

Regarding TDC, the heat release reached $95 \%$ at maximum hydrogen dose use, with increases being $23 \%$ to $52 \%$ for $\mathrm{xc}=6.76$ to 13.39 , which is comparative to classic fuel. The maxima in heat release tended to appear five crank angle degrees sooner per cycle, in correlation with the acceleration of heat release during the early stages of combustion when using hydrogen. These aspects are connected with the decrease of angle values related to the conventional Mass Fractions Burned (MFB), which were achieved sooner per cycle, i.e., closer to TDC, which correlates with the acceleration of the combustion process when using hydrogen; see Figure 11.

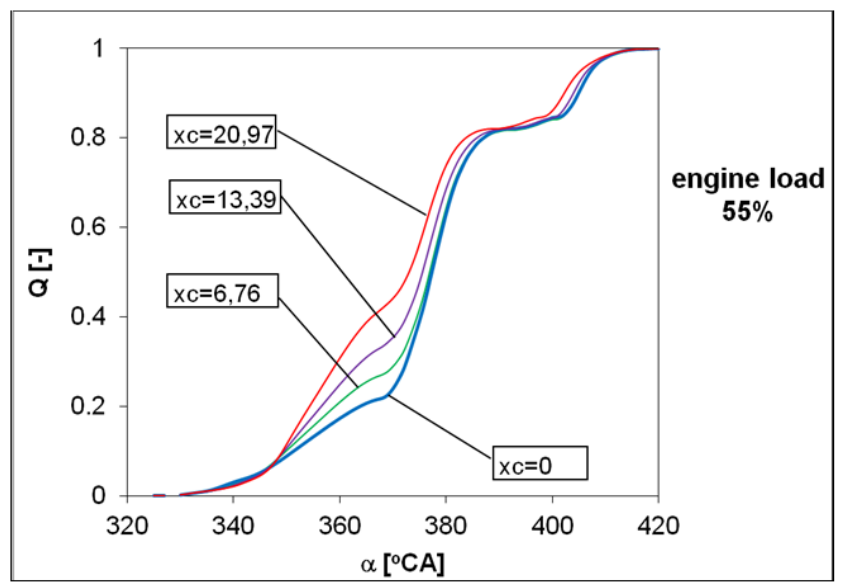

Figure 11. Heat release characteristics for different substitute ratios at 55\% engine load and a speed of $2000 \mathrm{~min}^{-1}$.

Thus, for hydrogen use, the Mass Fraction Burned (MFB) during the rapid phase of combustion occurred sooner per cycle, with $4^{\circ} \mathrm{CA},\left(50 \%-\mathrm{MFB}=377^{\circ} \mathrm{CA}\right.$ at $\mathrm{xc}=0$ versus $50 \%$-MFB $=373^{\circ} \mathrm{CA}$ at $\mathrm{xc}=20.97)$. Additionally, the total combustion duration decreased by $3^{\circ} \mathrm{CA}\left(90 \%-\mathrm{MFB}=405^{\circ}\right.$ $\mathrm{CA}$ at $\mathrm{xc}=0$ versus $90 \%-\mathrm{MFB}=402^{\circ} \mathrm{CA}$ at $\mathrm{xc}=20.97$ ); see Figure 12 . With the hydrogen addition, the $\Delta \alpha_{1-90 \%}$ combustion duration started to decrease and became comparable to that of to diesel fueling, with $3^{\circ} \mathrm{CA}$ for $\mathrm{xc}=20.97$ (from $\Delta \alpha_{1-90 \%}=70^{\circ} \mathrm{CA}$ with diesel fueling to $\Delta \alpha_{1-90 \%}=69^{\circ} \mathrm{CA}$ at $\mathrm{xc}=13.39$ or $\Delta \alpha_{1-90 \%}=67^{\circ} \mathrm{CA}$ at $\left.\mathrm{xc}=20.97\right)$. The tendency of decreasing combustion duration was related to the increase of peak pressure, the rate of maximum pressure rise and the rate of heat release, as noted previously under the same operating regime.

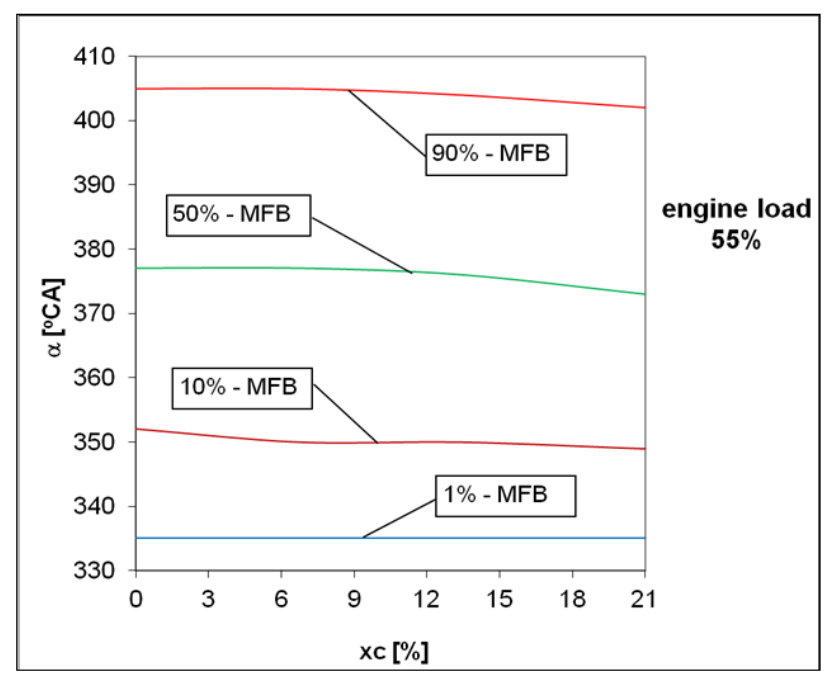

Figure 12. Angles of MFB versus substitute ratio at $55 \%$ engine load and a speed of $2000 \mathrm{~min}^{-1}$. 
In order to evaluate the combustion variability with hydrogen, the coefficients of variability (COV) of maximum pressure and indicated mean effective pressure (IMEP) were studied. In order to evaluate the fluctuation of the energy generated during combustion, which influences the rate of combustion in relation to the variance of the indicated mean effective pressure, which, in turn, affects torque and performance, the COV of IMEP was deemed to be suitable. Generally, the COV of maximum pressure is used to define the cycle variability of in-cylinder combustion for running regimes in the MBT injection timing range (Maximum Brake Torque). If the values of these coefficients do not surpass a limit of $10 \%$, then the engine is running properly [41].

For a measurement sample, the COV shows the relationship of the standard deviation, $\mathrm{S}_{x}$, to the arithmetic average of the measurement sample values, $x_{\text {average, }}$ for a sample of 250 cycles, as the following relation shows [41]:

$$
\operatorname{COV}_{X}[\%]=\frac{S_{X}}{X_{\text {average }}} \cdot 100
$$

where " $x$ " represents the $\mathrm{p}_{\max }$, IMEP and $(\mathrm{dp} / \mathrm{d} \alpha)_{\max }$.

At $2000 \mathrm{~min}^{-1}$ and $55 \%$ engine load, the increase of the substitute ratio led to an increase in COV for peak pressure from 0.32 to 0.7 at maximum xc.

With hydrogen use, the maximum value of COV for peak pressure did not exceed $3 \%$ and the limitation of xc was not necessary from this point of view; however, the increasing tendency should be taken into consideration; see Figure 13. The increasing tendency was much more obvious for $x c>10 \%$.

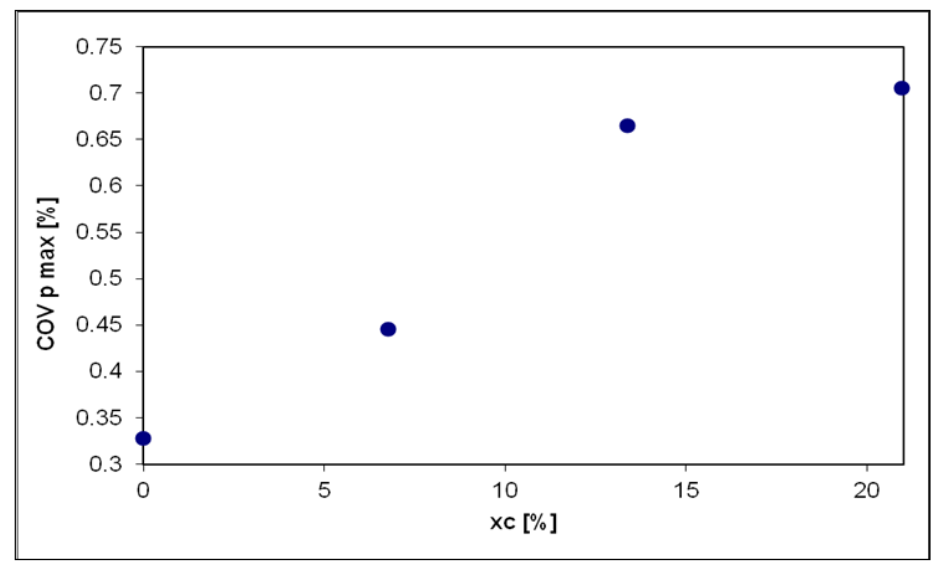

Figure 13. COV of peak pressure versus substitute ratio at $55 \%$ engine load and a speed of $2000 \mathrm{~min}^{-1}$.

With hydrogen addition in the inlet air, the IMEP increased by $2.6 \%$ at maximum $\mathrm{xc}$, but the dispersion between the values reached in combustion consecutive cycles started to increase. Thus, the COV of IMEP (see Figure 14) reached a value that was 1.2 times higher for maximum xc compared to that of a traditional fuel. Also, the increasing tendency meant that the COV values increased slightly, i.e., by $0.55 \%$ for $\mathrm{xc}=6.7$ to 20.9 .

Even the COV of IMEP increased at maximum xc in some combustion cycles when the maximum pressure did not exceed $p_{\max }=100$ bar and the maximum pressure rise rate did not surpass $(\mathrm{dp} / \mathrm{d} \alpha)_{\max }=4.3 \mathrm{bar} /{ }^{\circ} \mathrm{CA}$. The increase of combustion variability with the use of hydrogen was related to the ultralean air-hydrogen mixtures established inside the cylinder before combustion started.

Greater homogeneity of the air-hydrogen mixture, which burned very rapidly during the rapid phase, led to an increase in peak pressure and the maximum pressure rise rate, and to a decrease in the COV for the maximum pressure rise rate; see Figure 15. With hydrogen fueling, the COV of $(\mathrm{dp} / \mathrm{d} \alpha)_{\max }$ was 1.3 times lower at maximum xc compared to traditional fueling. 


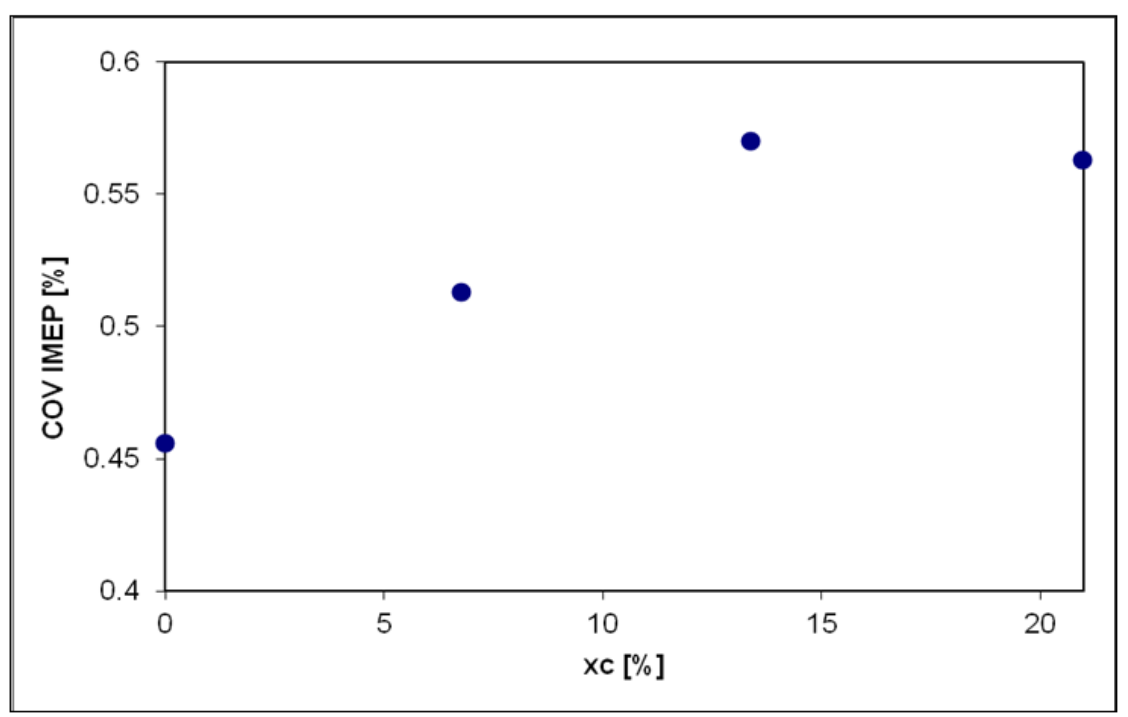

Figure 14. COV of IMEP versus substitute ratio at 55\% engine load and a speed of $2000 \mathrm{~min}^{-1}$.

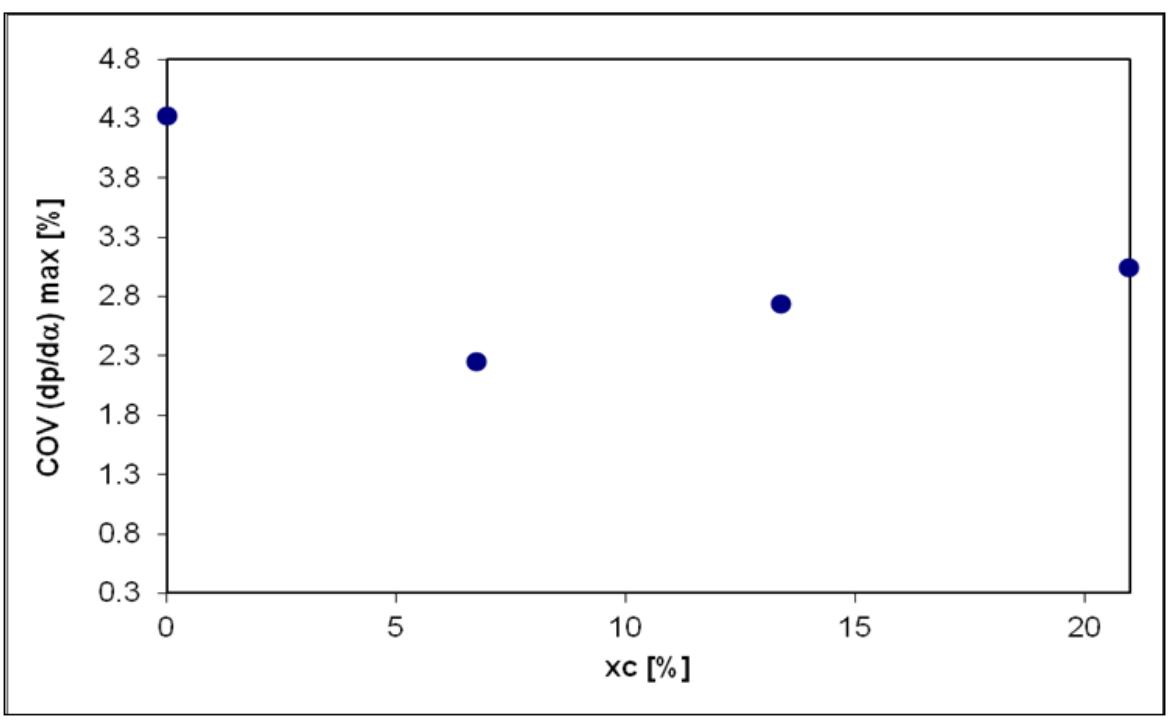

Figure 15. COV of $(\mathrm{dp} / \mathrm{d} \alpha)_{\max }$ versus substitute ratio at $55 \%$ engine load and a speed of $2000 \mathrm{~min}^{-1}$.

Regarding combustion variability, the applied substitute ratio values ensured the normal operation of the diesel engine with dual fueling.

With hydrogen addition, due to improved combustion, the $\mathrm{CO}_{2}$ emission level started to decrease with increasing the cyclic dose of hydrogen; see Figure 16. The level of $\mathrm{CO}_{2}$ emission decreased by $4 \%$ at $\mathrm{xc}=6.67$, by $8.3 \%$ for $\mathrm{xc}=13.39$ and by $14 \%$ at $\mathrm{xc}=20.97$. The continuous reduction of the BSEC with the increase of hydrogen cyclic quantity, i.e., by $5 \%$ at maximum xc (see Figure 2) was reflected in the decrease of the $\mathrm{CO}_{2}$ emission level.

The acceleration of the combustion process may be explained by the increase of the heat release rate. Meanwhile, the reduction of hydrocarbon fuel type with the increase of hydrogen quantity led to $14 \%$ and $28.5 \%$ decreases in unburned HC emission level for $\mathrm{xc}=6.76$ and $\mathrm{xc}=13.39$ to 20.97, respectively; see Figure 17. 


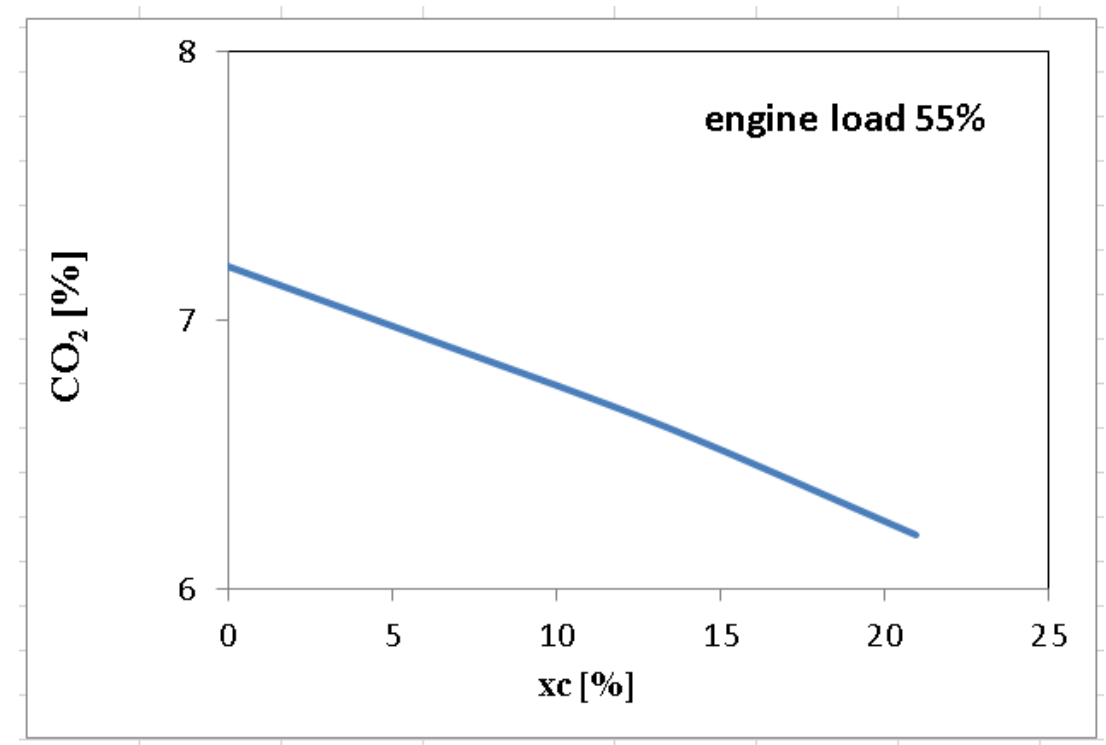

Figure 16. The $\mathrm{CO}_{2}$ emission level versus substitute ratio at $55 \%$ engine load and a speed of $2000 \mathrm{~min}^{-1}$.

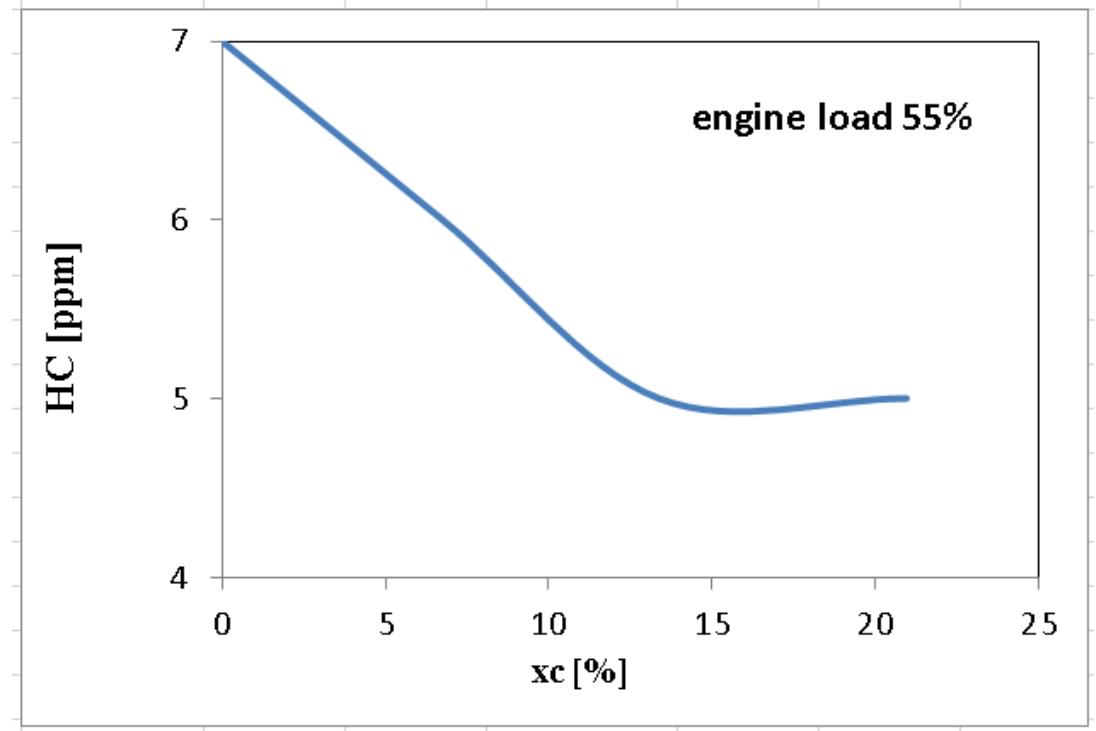

Figure 17. The HC emission level versus substitute ratio at $55 \%$ engine load and a speed of $2000 \mathrm{~min}^{-1}$.

With a 55\% load and a speed of $2000 \mathrm{rev} / \mathrm{min}$, the increase of heat release at maximum xc led to an increase in $\mathrm{NO}_{\mathrm{x}}$ emissions at large hydrogen doses; however, the obtained value was $6.8 \%$, i.e., under the value of traditional fuels; see Figure 18. For $\mathrm{xc}=6.76$ and 13.39 , the $\mathrm{NO}_{\mathrm{x}}$ emission level decreased by $20 \%$ and $16.7 \%$, respectively. The local richer mixture and the increase of water vapor molar fraction in the combustion products, with an influence on burned gas temperatures, may explain the decrease of $\mathrm{NO}_{\mathrm{x}}$ emissions. A similar phenomenon regarding $\mathrm{NO}_{\mathrm{x}}$ emissions was reported previously [23,24,28-30], showing that, in general, the $\mathrm{NO}_{x}$ level starts to decrease when hydrogen is used, but that increasing the hydrogen quantity may increase the $\mathrm{NO}_{\mathrm{x}}$ emission level. This is in accordance with the increases in combustion temperature and thermal losses [28]; consequently, the emission level is influenced by the quantity of hydrogen [30], and small hydrogen quantities are recommended [28-30]. 


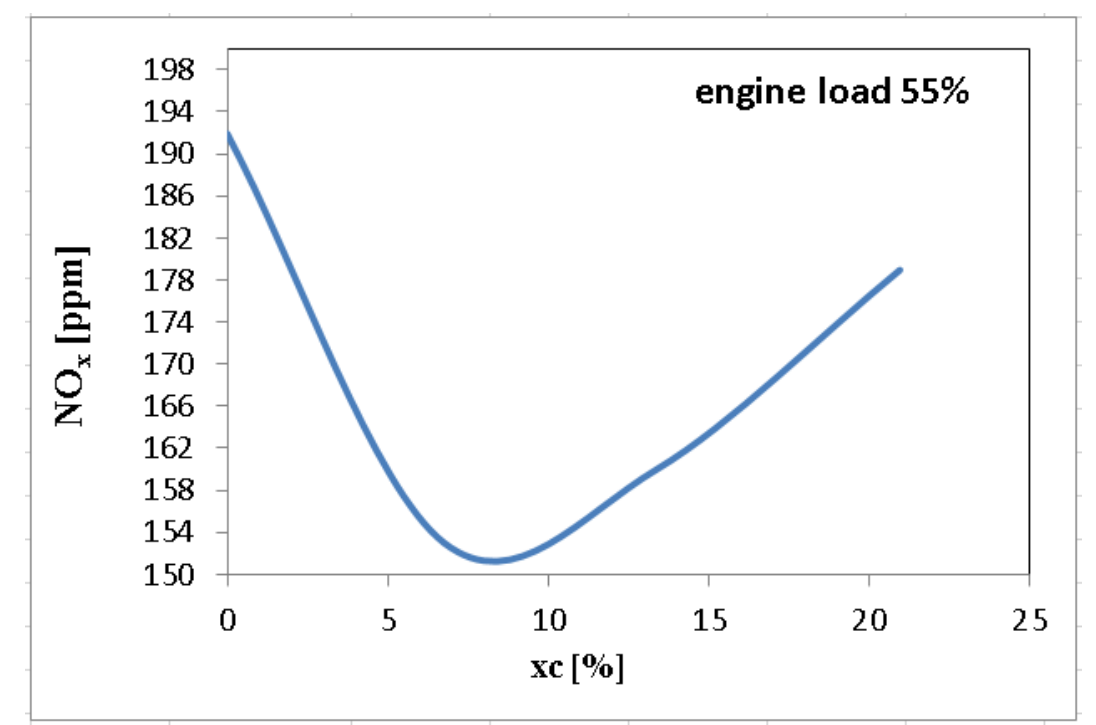

Figure 18. The $\mathrm{NO}_{\mathrm{x}}$ emission level versus substitute ratio at $55 \%$ engine load and a speed of $2000 \mathrm{~min}^{-1}$.

The smoke emission was evaluated by $\mathrm{K}$ smoke number. Its variation relative to the substitute ratio of diesel fuel for hydrogen is presented in Figure 19. The carbon content in the final mixture started to decrease with an increase of hydrogen cyclic quantity, with the smoke emission level decreasing by $24 \%$ for $\mathrm{xc}=6.76$, by $19 \%$ for $13.39 \%$ and by $14 \%$ at $\mathrm{xc}=20.97$. The decrease in the combustion rate of diffusive formed mixtures up to $26 \%$ with hydrogen fuel was in correlation with the reduction of the smoke emission level; see Figure 10.

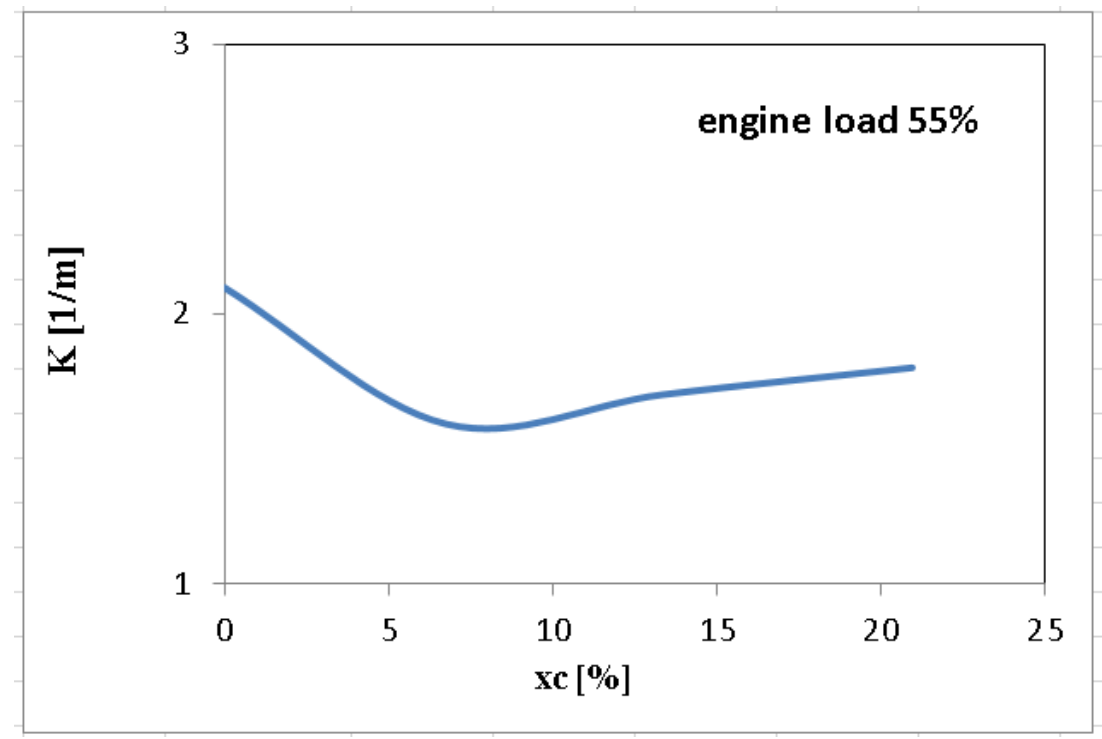

Figure 19. The $\mathrm{K}$ number versus substitute ratio at $55 \%$ engine load and a speed of $2000 \mathrm{~min}^{-1}$.

Similar tendencies regarding the reduction of pollutant emissions levels have been reported in papers describing the effects of hydrogen use in ICE $[23,24,27-30,52,53,55,56]$.

\section{Conclusions}

The contribution of the present paper to studies of ICE lies in measuring the optimal correlations among engine operating regime, diesel fuel and hydrogen cyclic quantities, supercharging pressure, combustion peak pressure, pollutant emissions levels and exhaust gas temperatures, measured during an experimental investigation into achieving maximum engine efficiency using hydrogen 
as an additional fuel. Another novelty aspect of the research is the observed correlation between diesel fuel consumption and engine load spread, which reflects a broadening of the conditions under which engine load quality adjustments can be made. With the same diesel fuel consumption, engine operation at higher power becomes possible, with the wideness of load used increasing by $7.5 \mathrm{~kW}$. Thus, using hydrogen as a fuel and tuning the transmission system to ensure the interlacing of qualitative and quantitative load adjustment, it becomes possible to adjust the engine load over a larger range. The use of hydrogen as a fuel for K9K automotive diesel engines ensures a reduction of the Break Specific Energetic Consumption for each engine load due to an improved combustion process compared to that obtained using a homogeneous air-hydrogen mixture. Thus, compared to traditional fueling, it is possible to achieve a significant economy of diesel fuel and lower energetic specific consumption while achieving similar engine power and increased engine brake efficiency under all load regimes. Because the fuel quantity which burns in the rapid phase increases with the addition of hydrogen, the peak pressure and maximum pressure rise rate start to increase for $55 \%$ load and $2000 \mathrm{~min}^{-1}$, but the peak values reached do not exceed the normal values. Hydrogen ensures an acceleration of the combustion process and an increase of the cyclic quantity and rate of heat release, with the amount of heat being released in the premixed phase being much larger and the variability of the maximum pressure rise rate being reduced in correlation with the higher combustion velocity of hydrogen. The acceleration of combustion is related to a decrease in the combustion duration, with $10 \%-\mathrm{MFB}$ being achieved earlier in the cycle, nearer to TDC, in correlation with the increase of peak pressure, maximum pressure rise rate and amount of heat released into premixed phase of combustion.

Compared to classic fueling, with hydrogen fueling, an ultralean mixture, established in the cylinder before combustion starts, leads to a slight increase in combustion variability, with COV values for peak pressure and IMEP being increased 2.1 and 1.2 times, respectively.

Generally, hydrogen use offers reduced greenhouse gas and pollutant emissions, but the decrement degree depends on the hydrogen cyclic dose. Hydrogen use at an operating regime of $55 \%$ load and a speed of $2000 \mathrm{rev} / \mathrm{min}$ led to a $14 \%$ reduction of $\mathrm{CO}_{2}$ emissions levels due to an improved combustion process. When using hydrogen, the unburned HC emission levels decreased by $28.5 \%$, correlating with a reduction in the combustion rate of diffusive mixtures and in diesel fuel consumption. The addition of hydrogen led to an increase in the molar fraction of water vapors in the combustion products, influencing the combustion temperature and decreasing the $\mathrm{NO}_{\mathrm{x}}$ emission levels by $20 \%$. The reduction of the carbon content in the final mixture when hydrogen replaced diesel fuel led to a $24 \%$ decrease in the smoke emission.

Hydrogen is a viable alternative fuel for automotive diesel engines; its use offers an increase of thermal efficiency without requiring significant changes to the engine design.

Author Contributions: Conceptualization, A.C., C.P., N.N., C.N., G.L. and D.F.; methodology, A.C., C.P., N.N., C.N. and D.F.; software-on test bed, A.C., C.P., N.N., C.N. and D.F.; validation, A.C., C.P. and N.N.; formal analysis, A.C., C.P., N.N., C.N., G.L. and D.F.; investigation, A.C., C.P., N.N., C.N., G.L. and D.F.; resources, A.C., C.P., N.N., N.C., G.L. and D.F.; data curation, A.C., C.P., N.N. and C.N.; writing-original draft preparation, A.C., C.P., N.N., C.N., G.L. and D.F.; writing_-review and editing, A.C., C.P., N.N., C.N. and G.L.; visualization, A.C., C.P., N.N., C.N., G.L. and D.F.; supervision, A.C., C.P., N.N. and G.L.; project administration, A.C., C.P., N.N. and G.L.; funding acquisition, A.C., C.P., N.N., G.L. and D.F. All authors have read and agreed to the published version of the manuscript.

Funding: This work was supported by a grant of the Romanian Ministery of Research and Innovation, CCCDI-UEFISCDI, project number PN-III-P1-1.2-PCCDI-2017-0404/31PCCDI/2018, within PNCDI III.

Acknowledgments: The authors address special thanks to AVL GmbH Graz Austria for providing the necessary equipment.

Conflicts of Interest: The authors declare no conflict of interest. 


\section{Abbreviations}

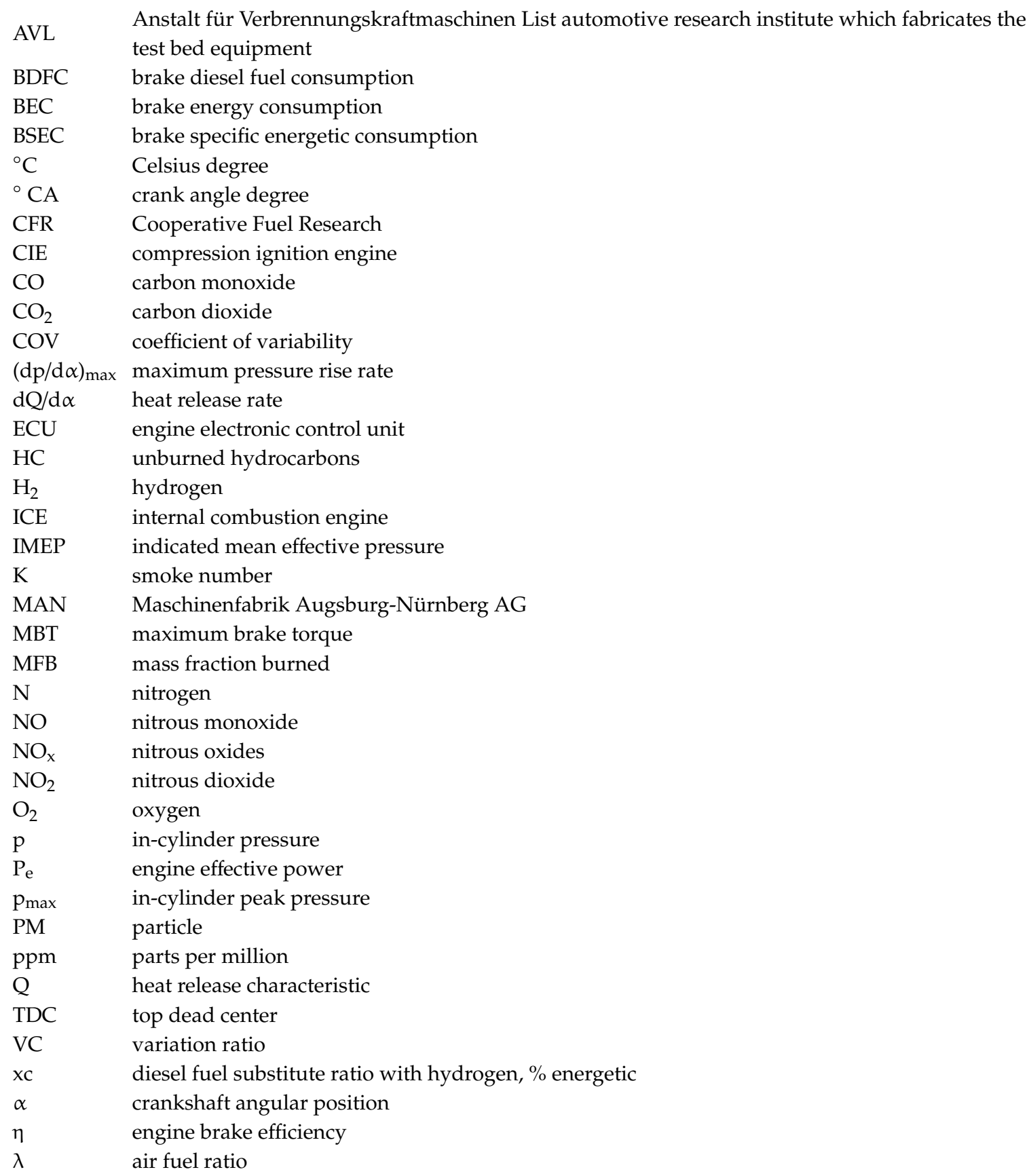

\section{References}

1. Vaz, C.R.; Rauen, T.R.S.; Lezana, A.G.R. Sustainability and Innovation in the Automotive Sector: A Structured Content Analysis. Sustainability 2017, 9, 880. [CrossRef]

2. Zhao, F.; Chen, K.; Hao, H.; Liu, Z. Challenges, Potential and Opportunities for Internal Combustion Engines in China. Sustainability 2020, 12, 4955. [CrossRef]

3. Iuga, A.N.; Popa, V.N.; Popa, L.I. Comparative Analysis of Automotive Products Regarding the Influence of Eco-Friendly Methods to Emissions' Reduction. Energies 2018, 12, 6. [CrossRef]

4. Millo, F.; Piano, A.; Peiretti Paradisi, B.; Marzano, M.R.; Bianco, A.; Pesce, F.C. Development and Assessment of an Integrated 1D-3D CFD Codes Coupling Methodology for Diesel Engine Combustion Simulation and Optimization. Energies 2020, 13, 1612. [CrossRef] 
5. Mishra, D.P.; Kumar, P. Experimental investigation of laminar LPG- $\mathrm{H}_{2}$ jet diffusion flame with preheated reactants. Fuel 2008, 87, 3091-3095. [CrossRef]

6. Masood, M.; Ishrat, M.M. Computer simulation of hydrogen-diesel dual fuel exhaust gas emissions with experimental verification. Fuel 2008, 87, 1372-1378. [CrossRef]

7. Rosca, R. Controlul Emisiilor Poluante la Motorul Diesel (Control of the Pollutant Emissions at the Diesel Engine). Available online: http://rrosca.tripod.com/emisii_diesel.pdf (accessed on 19 April 2019).

8. UNFCCC Paris Agreement. In Proceedings of the Conference of the Parties on its Twenty-First Session, Paris, France, 30 November-13 December 2015.

9. Christodoulou, F.; Megaritis, A. Experimental investigation of the effects of separate hydrogen and nitrogen addition on the emissions and combustion of a diesel engine. Int. J. Hydrogen Energy 2013, 38, $10126 \mathrm{e} 40$. [CrossRef]

10. Karim, G. Hydrogen as a spark ignition engine fuel. Int. J. Hydrogen Energy 2003, 28, 569-577. [CrossRef]

11. Masood, M.; Ishrat, M.; Reddy, A. Computational combustion and emission analysis of hydrogen diesel blends with experimental verification. Int. J. Hydrogen Energy 2007, 32, 2539-2547. [CrossRef]

12. Lambe, S.; Watson, H. Optimizing the design of a hydrogen engine with pilot diesel fuel ignition. Int. J. Veh. Des. 1993, 14, 370-389.

13. Lilik, G.; Zhang, H.; Herreros, J. Hydrogen assisted diesel combustion. Int. J. Hydrogen Energy 2010, 35, 4382-4398. [CrossRef]

14. Saravanan, V.N.; Nagarajan, G.; Sanjay, G.; Dhanasekaran, C.; Kalaiselvan, K.M. Combustion analysis on a DI diesel engine with hydrogen in dual fuel mode. Fuel 2008, 87, 8. [CrossRef]

15. Ismail, T.; Ramzy, K.; Abelwhab, M.; Elnaghi, B.; Abd El-Salam, M. Performance of hybrid compression ignition engine using hydroxy (hho) from dry cell. Energy Convers. Manag. 2018, 155, 287-300. [CrossRef]

16. Communication from the Commission to the European Parliament, the Council, the European Economic and Social Committee and the Committee of the Regions a Roadmap for Moving to a Competitive Low Carbon Economy in 2050. Brussels, 8.3.2011 COM (2011) 112 Final. Available online: http://www.europarl. europa.eu/meetdocs/2009_2014/documents/com/com_com(2011)0112_/com_com(2011)0112_en.pdf (accessed on 19 April 2019).

17. Sastri, M.V.C. Hydrogen energy research-and-development in India e an overview. Int. J. Hydrogen Energy 1987, 12, 12-18. [CrossRef]

18. Verhelst, S.; Sierens, R. Hydrogen engine-specific properties. Int. J. Hydrogen Energy 2001, 26, 987-990. [CrossRef]

19. Polverino, P.; D'Aniello, F.; Arsie, I.; Pianese, C. Study of the energetic needs for the on-board production of Oxy-Hydrogen as fuel additive in internal combustion engines. Energy Convers. Manag. 2019, 179, 17. [CrossRef]

20. Yousefi, A.; Birouk, M.; Lawler, B.; Gharehghani, A. Performance and emissions of a dual-fuel pilot diesel ignition engine operating on various premixed fuels. Energy Convers. Manag. 2015, 106, 15. [CrossRef]

21. Popa, M.G.; Pana, C.; Negurescu, N. Diesel Engines Processes, 1st ed.; Matrix Rom: Bucharest, Romania, 2003; pp. 1-706.

22. Verma, S.; Das, L.M.; Bhatti, S.S.; Kaushik, S.C. A comparative exergetic performance and emission analysis of pilot diesel dual-fuel engine with biogas, CNG and hydrogen as main fuels. Energy Convers. Manag. 2017, 151, 13. [CrossRef]

23. Diaz, G.J.A.; Montoya, J.P.G.; Martinez, L.A.C.; Olsen, D.B.; Navarro, A.S. Influence of engine operating conditions on combustion parameters in a spark ignited internal combustion engine fueled with blends of methane and hydrogen. Energy Convers. Manag. 2019, 181, 10. [CrossRef]

24. Kakoee, A.; Bakhshan, Y.; Aval, S.M.; Gharehghani, A. An improvement of a lean burning condition of natural gas/diesel RCCI engine with a pre-chamber by using hydrogen. Energy Convers. Manag. 2018, 166, 10. [CrossRef]

25. Prechtl, P.; Dorer, F.; Mayinger, F.; Vogel, C.; Schnurbein, V. Energy Conversion in a Hydrogen Fuelled Diesel Engine: Optimization of the Mixture Formation and Combustion, Heat Transfer Enhancement of Heat Exchangers; Kluwer Academic Publishers: Dordrecht, The Netherlands, 1999; pp. 1-9.

26. Pana, C.; Negurescu, N.; Cernat, A.; Nutu, C.; Mirica, I.; Fuiorescu, D. Experimental aspects of the hydrogen use at diesel engine. Procedia Eng. 2017, 181, 649-657. [CrossRef] 
27. Saravanan, N.; Nagarajan, G.; Dhanasekaran, C.; Kalaiselvan, K.M. Experimental Investigation of Hydrogen Fuel Injection in DI Dual Fuel Diesel Engine; SAE Technical Papers 2007-01-1465; SAE International: Warrendale, PA, USA, 2007. [CrossRef]

28. Negurescu, N.; Pană, C.; Popa, M.G.; Cernat, A. Performance Comparison Between Hydrogen and Gasoline Fuelled SI Engine. Therm. Sci. 2011, 15, 4. [CrossRef]

29. Shahad, H.A.K.; Abdul-Hadi, N. Experimental Investigation of the Effect of Hydrogen Manifold Injection on the Performance of Compression Ignition Engines. World Acad. Sci. Eng. Technol. 2011, 76, 11.

30. Talibi, M.; Hellier, P.; Morgan, R.; Lenartowicz, C.; Ladommatos, N. Hydrogen-diesel fuel co-combustion strategies in light duty and heavy duty CI engines. Int. J. Hydrogen Energy 2018, 43, 12. [CrossRef]

31. Talibi, M.; Hellier, P.; Balachandran, R.; Ladommatos, N. Effect of hydrogen-diesel fuel co-combustion on exhaust emissions with verification using an in-cylinder gas sampling technique. Int. J. Hydrogen Energy 2014, 39, 15088-15102. [CrossRef]

32. Pechlivanoglou, G. Hydrogen Enhanced Combustion History. Applications and Hydrogen Supply by Plasma Reforming; University of Oldenburg: Oldenburg, Germany, 2005; PPRE 2005-2007.

33. Tomita, E.; Kawahara, N.; Piao, Z.; Fujita, S. Hydrogen Combustion and Exhaust Emissions Ignited with Diesel Oil in a Dual Fuel Engine; SAE Technical Paper 2001-01-3503; SAE International: Warrendale, PA, USA, 2001. [CrossRef]

34. Chintala, V.; Subramanian, K.A. Experimental investigation of hydrogen energy share improvement in a compression ignition engine using water injection and compression ratio reduction. Energy Convers. Manag. 2016, 108, 13. [CrossRef]

35. Yadav, V.S.; Soni, S.L.; Sharma, D. Performance and emission studies of direct injection C.I. engine in duel fuel mode (hydrogen-diesel) with EGR. Int. J. Hydrogen Energy 2012, 36, 10.

36. Bari, S.; Esmaeil, M.M. Effect of $\mathrm{H}_{2} / \mathrm{O}_{2}$ addition in increasing the thermal efficiency of a diesel engine. Fuel 2010, 89, 5. [CrossRef]

37. Kerkal, G.; Pawale, K.; Dhumal, A. Diesel Engine with Hydrogen in Dual Fuel Mode: A Review. Int. J. Res. Appl. Sci. Eng. Technol. 2017, 5, 10.

38. Deb, M.; Sastry, G.R.K.; Bose, P.K.; Banerjee, R. An experimental study on combustion, performance and emission analysis of a single cylinder, 4-stroke DI-diesel engine using hydrogen in dual fuel mode of operation. Int. J. Hydrogen. Energy 2015, 4, 12. [CrossRef]

39. Santoso, W.B.; Bakar, R.A.; Nur, A. Combustion characteristics of diesel diesel-hydrogen duel fuel engine at low load. In Proceedings of the International Conference on Sustainable Energy Engineering and Application 2012, Nagasaki, Japan, 11-14 November 2012.

40. Luo, Q.; Sun, B. Experiments on the effect of engine speed, load, equivalence ratio, spark timing and coolant temperature on the energy balance of a turbocharged hydrogen engine. Energy Convers. Manag. 2018, 162, 12. [CrossRef]

41. Heywood, J.B. Internal Combustion Engines Fundamentals; McGraw-Hill Book Company: New York, NY, USA, 1988; pp. 1-930.

42. Shin, B.; Cho, Y.; Han, D.; Song, S.; Chun, K.M. Investigation of the effects of hydrogen on cylinder pressure in a split-injection diesel engine at heavy EGR. Int. J. Hydrogen Energy 2011, 36, 13158-13170. [CrossRef]

43. Das, L.M. Hydrogen-fueled internal combustion engines. In Compendium of Hydrogen Energy, Hydrogen Energy Conversion; Woodhead Publishing Ltd.: Sawston, UK; Cambridge, UK, 2016; Volume 3, pp. 177-217.

44. Dell, R.M.; Rand, A.J.D. Hydrogen, Fuel Cells and Fuel Cell Vehicles. In Towards Sustainable Road Transport; Elsevier: Amsterdam, The Netherlands, 2014. [CrossRef]

45. Sorensen, B.; Spazzafumo, G. Hydrogen and Fuel Cells, 3rd ed.; Elsevier: Amsterdam, The Netherlands, 2018. [CrossRef]

46. Verhelst, S.; Wallner, T. Hydrogen-fueled internal combustion engines. Prog. Energy Combust. Sci. 2009, 35, 490-527. [CrossRef]

47. Mansor, M.R.A.; Abbood, M.M.; Mohamad, T.I. The influence of varying hydrogen-methane-diesel mixture ratio on the combustion characteristics and emissions of a direct injection diesel engine. Fuel 2017, 190, 281-291. [CrossRef]

48. Sandalci, T.; Karagöz, Y. Experimental investigation of the combustion characteristics, emissions and performance of hydrogen port fuel injection in a diesel engine. Int. J. Hydrogen Energy 2014, 39, 18480-18489. [CrossRef] 
49. Dhole, A.E.; Yarasu, R.B.; Lata, D.B.; Baraskar, S.S. Mathematical modeling for the performance and emission parameters of dual fuel diesel engine using hydrogen as secondary fuel. Int. J. Hydrogen Energy 2014, 39, 12991-13001. [CrossRef]

50. Karagöz, Y.; Sandalc1, T.; Yüksek, L.; Dalkılıç, A.S.; Wongwises, S. Effect of hydrogen-diesel dual-fuel usage on performance, emissions and diesel combustion in diesel engines. Adv. Mech. Eng. 2016, 8, 8. [CrossRef]

51. Kavtaradze, R.; Natriashvili, T.; Gladyshev, S. Hydrogen-Diesel Engine: Problems and Prospects of Improving the Working Process; SAE Technical Paper 2019-01-0541; WCX SAE World Congress Experience: Warrendale, PA, USA, 2019; p. 15, ISSN 0148-7191.

52. Ghazal, O.H. Combustion analysis of hydrogen-diesel dual fuel engine with water injection technique. Case Stud. Therm. Eng. 2019, 13, 100380. [CrossRef]

53. Monemian, E.; Cairns, A. Hydrogen Fumigation on HD Diesel Engine: An Experimental and Numerical Study. In Diesel and Gasoline Engines; IntechOpen: London, UK, 2020. [CrossRef]

54. Lešnik, L.; Kegl, B.; Torres-Jiménez, E.; Cruz-Peragón, F. Why we should invest further in the development of internal combustion engines for road applications. Oil Gas Sci. Technol. Rev. d'IFP Energies Nouv. 2020, 75, 56. [CrossRef]

55. Yip, H.L.; Srna, A.; Yuen, A.C.Y.; Kook, S.; Taylor, R.A.; Yeoh, G.H.; Medwell, P.R.; Chan, Q.N. A Review of Hydrogen Direct Injection for Internal Combustion Engines: Towards Carbon-Free Combustion. Appl. Sci. 2019, 9, 4842. [CrossRef]

56. Saroj, C.D.; Dhirendra, K.A.; Ambica, N.T.; Mohanty, P. A review on performance of biogas and hydrogen on diesel engine in dual fuel mode. Fuel 2020, 260, 116337. [CrossRef]

Publisher's Note: MDPI stays neutral with regard to jurisdictional claims in published maps and institutional affiliations. 